Article

\title{
An Analysis of the Nutritional and Health Values of Caulerpa racemosa (Forsskål) and Ulva fasciata (Delile)-Two Chlorophyta Collected from the Philippines
}

\author{
Rexie P. Magdugo ${ }^{1}$, Nolwenn Terme ${ }^{1}$, Marie Lang ${ }^{1}{ }^{\oplus}$, Hugo Pliego-Cortés ${ }^{1}\left(\mathbb{D}\right.$, Christel Marty ${ }^{1}$, \\ Anicia Q. Hurtado ${ }^{2}$, Gilles Bedoux ${ }^{1}$ (D) and Nathalie Bourgougnon ${ }^{1, *}$ \\ 1 Laboratoire de Biotechnologie et Chimie Marines, EA3884, UBS, IUEM, F-56000 Vannes, France; \\ magdugo@univ-ubs.fr (R.P.M.); nolwenn.terme@univ-ubs.fr (N.T.); marie.lang@univ-ubs.fr (M.L.); \\ hugopliegocortes@gmail.com (H.P.-C.); christel.marty@univ-ubs.fr (C.M.); gilles.bedoux@univ-ubs.fr (G.B.) \\ 2 Integrated Services for the Development of Aquaculture and Fisheries (ISDA) Inc., MacArthur Highway, \\ Tabuc Suba, Jaro, Iloilo City 5000, Philippines; anicia.hurtado@gmail.com \\ * Correspondence: nathalie.bourgougnon@univ-ubs.fr; Tel.: +33-(0)2-970-17-070
}

Academic Editor: Benoît Chénais

Received: 19 May 2020; Accepted: 16 June 2020; Published: 24 June 2020

\begin{abstract}
Polysaccharides, lipids and amino acid profiles were investigated to understand the nutritional value of Caulerpa racemosa and Ulva fasciata from the Philippines. The results revealed that both species contain high amounts of proteins $(8.8-19.9 \%$ for C. racemosa and $8.0-11.1 \%$ for U. fasciata). The portions of the total amino acids that were essential amino acids (EAAs) $(45.28 \pm 0.12 \%$ for C. racemosa and $42.17 \pm 0.12 \%$ for $U$. fasciata) out were comparable to $\mathrm{FAO} / \mathrm{WHO}$ requirements. Leucine, valine, isoleucine, and lysine are the dominant EAAs in C. racemosa, while leucine, valine, lysine, and phenylalanine are those in $U$. fasciata. The fatty acid profiles are dominated by monounsaturated fatty acids and polyunsaturated fatty acids in C. racemosa (56.2\%), while saturated fatty acids $(72.1 \%)$ are dominant in $U$. fasciata. High C18/C20 polyunsaturated fatty acid ratios were recorded in both species. Mineral contents for both seaweeds were within levels considered safe for functional foods. Total pigment content of $C$. racemosa $(140.84 \mathrm{mg} / \mathrm{g} \mathrm{dw})$ was almost 20 times higher than that of U. fasciata $(7.54 \mathrm{mg} / \mathrm{g} \mathrm{dw})$. Hot water extract (HWE) from C. racemosa showed in vitro antiherpetic activity without cytotoxicity. Nutritional characteristics confirmed that $C$. racemosa could be potentially used as a nutritious and functional food items for human consumption.
\end{abstract}

Keywords: human food; amino acids; lipids; green seaweeds; biological activities

\section{Introduction}

Many years ago, the Greek physician Hippocrates emphasized the importance of food and good health [1]. Even today, foods satisfy hunger, provide necessary nutrients, improve the physical and mental welfare of consumers, and prevent nutrition-related diseases like cardiovascular disease and osteoporosis [2,3]. Population growth drives the need to find new protein, fiber, and mineral sources to feed future populations and fight food insecurity. Insects and marine algae have been proposed as novel and sustainable foods [4]. Marine macroalgae contain significant quantities of not only vitamins, minerals, dietary fibers, proteins, and polysaccharides, but also various functional polyphenols, antioxidants, pigments, and lipids $[2,5,6]$. Biochemical contents can vary with species, geographical location, season, and temperature. Marine macroalgae exhibit a wide diversity of minerals and trace elements, such as sodium, calcium, chlorine, magnesium, zinc, and copper. Algal protein content is generally high; this is especially the case for red algae, in which protein content represents $40 \%$ of the 
dry matter [7-9]. Furthermore, the storage polysaccharides (starch, laminarin, floridoside) are diverse. Cell walls present low cellulose and hemicellulose contents and original phycocolloids (alginates, carrageenan, agars). Lipids (more particularly, polyunsaturated fatty acids), sterols, and vitamins such as vitamins $\mathrm{C}$ or B12 with antioxidant properties are also present in macroalgae. The search for new food trends is expected to increase in the future and encourage the consumption of algae. These trends include eating less meat, eating vegan products (in favor of vegetable proteins), growing concerns about all aspects of sustainable and clean food production, and "snacking". With these changes in attitude, the integration of macroalgae as an alternative source in the daily diet has immense potential.

The Philippines is known for its rich flora, and its marine algae are a significant and diversified form of natural crop production. There are 1291 taxa of marine macrobenthic algae [10], and many species (350) are of economic importance as food and sources of industrial products such as polysaccharides, bioactive and natural nutritional products, and growth-promoting substances. The Seaweed Industry Association of The Philippines (SIAP) reported that the total production of all types of dried seaweeds in the Philippines from 2011-2015 was an average of almost 88,000 metric tons per annum. The local price of macroalgae ranged from $\$ 0.45$ to $\$ 0.89$ per kilogram throughout the year, according to sources in significant cities such as Tawi-Tawi, Zamboanga, Palawan, Cebu, and Manila [11]. The local price of macroalgae is considered affordable to average Filipinos, especially for those who live in big cities. Farming of Caulerpa and Ulva is expanding worldwide [5,11-13] to meet this growing demand from the health food market. In the Philippines, edible Caulerpa spp. (e.g., C. lentillifera, C. peltata, C. racemosa, C. sertularioides, and C. taxifolia) [5] were cultivated in sufficient amounts with Kappaphycus sp. and Eucheuma sp. [11], while Ulva spp. was planned to be cultivated along with Halymenia spp., Sargassum spp., and Pyropia spp. [11]. Following the prohibition of cultivation in mangrove areas, the production of Caulerpa declined. However, promising studies have recently been conducted in open-sea cultivation [14]. The Ulva spp. are encouraged by the Philippine government to be developed as a potential human and animal food, as well as a biogas feedstock. Several Ulva species are listed: $U$. lactuca, $U$. rigida, and $U$. fasciata. Meanwhile, Caulerpa consists mainly of two species, C. lentillifera and C. racemosa, which are the third most cultivated macroalgae in many parts of East Asia [15]. Consumers highly appreciate their delicate flavor and crisp texture, so these species are called "Green Caviar." Both Caulerpa and Ulva present many uses as human or animal food, and they are a source of minerals such as calcium, potassium, magnesium, sodium, copper, iron, zinc, and vitamin E. Culinary preparation varies according to species and country. Seaweeds can be consumed dry, fresh, boiled, in salads, as condiments, or cooked [16]. Some biological activities, such as antifungal activities, lowering blood pressure, or anthelmintic activities, are also mentioned [17-19]. Ulva and Caulerpa species have long been listed in the FAO database as two of the main macroalgae for commercial use and especially as direct food for human beings in various parts of the world [20]. Both green seaweeds constitute promising candidates as functional foods naturally enriched in nutrients and various health-promoting compounds. In the Philippines, these species of green seaweeds offer social and economic benefits and have a high level of consumer acceptance [16]. C. racemosa could be packed fresh in baskets lined with banana leaves or preserved in brine-cured or salted form [21]. Ulva is used in the form of fresh salad or as an ingredient in various food preparations [22]. In aquaculture, Ulva lactuca and $U$. rigida are also used as an alternative source of nutrients for aquafeeds, replacing soybean meal in the diet of shrimp [23]. Despite this information, little is known about the nutritional properties or biological activities of compounds extracted from Caulerpa racemosa and Ulva fasciata. De Gaillande et al. [5] presented a review in 2017 about the consumption, nutritional value, and farming of Caulerpa in the Indo-Pacific region, describing a genus rich in proteins, fibers, minerals, vitamins, polyunsaturated fatty acids, and bioactive antioxidants.

Little is known about the nutritional properties or biological activities [24,25] of the Caulerpa and Ulva species from the Philippines. This study was conducted to give additional information on the potential of wild Caulerpa and Ulva species from this country. The present study therefore deals with the clarification of the fatty acid composition in relation to total lipids, along with the characterization of cell 
wall polysaccharides, proteins, amino acids, mineral compositions, and nutritional values. Furthermore, this study evaluates of the antiviral activity of parietal polysaccharides and the antioxidant activities of the different fractions in the context of health.

\section{Results}

\subsection{Biochemical Composition Analysis of Raw Seaweeds and Their Extracts}

The biochemical composition of the two green seaweeds, the hot water extract from Caulerpa racemosa and the crude ulvan from Ulva fasciata, are shown in Table 1. C. racemosa as raw seaweed presented high neutral sugar content (31.2\%), followed by ash (29.4\%), protein (19.9\%), and sulfate group $(13.0 \%)$ contents. The biochemical analysis of raw seaweed from $U$. fasciata indicated a composition rich in sulfate groups (25.4\%), followed by total sugars $(25.0 \%)$, ash (23.3\%), and uronic acids $(20.7 \%)$. Protein content constituted a little over $1 / 10(11.1 \%)$ of the dry matter. Carbohydrate contents, including sulfated polysaccharides (corresponding to uronic acids, sulfate groups, and neutral sugars) in C. racemosa and U. fasciata, were about $47.8 \%$ and $71.1 \%$, respectively. For C. racemosa, the hot water extract (HWE) with 13\% yield presented neutral sugars $(16.6 \%)$, sulfates $(10.5 \%)$, and proteins $(8.8 \%)$. Finally, the $U$. fasciata crude ulvan polysaccharide yield represented $23.71 \%$, with major components including uronic acids (10\%), neutral sugars $(9.5 \%)$, and proteins $(8.0 \%)$.

Table 1. Biochemical composition (\% of dry weight) of raw and purified fractions from Caulerpa racemosa and ulvan from Ulva fasciata.

\begin{tabular}{ccccccccc}
\hline \multicolumn{7}{c}{ Content (\% Dry Algal Material) } \\
\hline Sample & Yield & Proteins & Lipids & $\begin{array}{c}\text { Uronic } \\
\text { Acids }\end{array}$ & $\begin{array}{c}\text { Sulfate } \\
\text { Groups }\end{array}$ & $\begin{array}{c}\text { Neutral } \\
\text { Sugars }\end{array}$ & Polyphenols & Ash \\
\hline $\begin{array}{c}\text { C. racemosa } \\
\text { Raw }\end{array}$ & & $19.9 \pm 0.5$ & 4.5 & $3.6 \pm 0.4$ & $13.0 \pm 1.5$ & $31.2 \pm 4.9$ & $4.9 \pm 1.6$ & $29.4 \pm 0.9$ \\
HWE & 13.0 & $8.8 \pm 0.9$ & $/$ & $1.6 \pm 0.4$ & $10.5 \pm 0.3$ & $16.6 \pm 1.7$ & $2.4 \pm 0.9$ & $/$ \\
\hline $\begin{array}{c}\text { U. fasciata } \\
\text { Raw }\end{array}$ & & $11.1 \pm 0.7$ & 4.1 & $20.7 \pm 4.8$ & $25.4 \pm 0.3$ & $25.0 \pm 3.5$ & $5.8 \pm 0.8$ & $23.3 \pm 2.2$ \\
Crude ulvan & 23.71 & $8.0 \pm 1.2$ & $/$ & $10.0 \pm 0.2$ & $3.12 \pm 0.1$ & $9.5 \pm 1.3$ & $5.0 \pm 1.2$ & $/$ \\
\hline \multicolumn{7}{c}{ Values are means $\pm \mathrm{SD}(n=9)$ except for lipids. / = not determined. }
\end{tabular}

\subsection{Fatty Acid Methyl Ester (FAME) Analysis}

The fatty acid (FA) content of C. racemosa represents $10.3 \%$ of the total lipid (TL) fraction and therefore $463 \mathrm{mg} / 100 \mathrm{~g}$ of dry seaweed. For $U$. fasciata, the FA content is $10.7 \%$ of TLs and therefore represents $439 \mathrm{mg} / 100 \mathrm{~g}$ of dry seaweed. The FA compositions of C. racemosa and U. fasciata are shown in Table 2. Unsaturated fatty acids (monounsaturated fatty acids (MUFA) and polyunsaturated fatty Acids (PUFA)) were the primary fatty acids in C. racemosa (56.2\% of total fatty acids (\% TFAs)). In contrast, in U. fasciata, saturated fatty acids (SFAs) were the primary fatty acids (72.1\% of TFAs). Unsaturated fatty acids from C. racemosa represented a variety of structures, with 14 different FAs identified by GC ranging from $0.4 \%$ to $28.1 \%$ of total FAs. The main FA detected was oleic acid (C18:1 $\omega 9,28.1 \%$ of TFAs). In $U$. fasciata, palmitic acid was the most abundant FA, accounting for $59.9 \%$ TFAs, which amounts to $83 \%$ of the SFAs. There was less diversity in unsaturated FA, with six different MUFAs and five different PUFAs in U. fasciata compared to C. racemosa. The MUFA and PUFA contents ranged between $<0.1$ and $5.9 \%$ and between $<0.1$ and $5.3 \%$ of TFAs, respectively.

The nutritional quality indexes calculated with the fatty acid profiles of C. racemosa and U. fasciata are presented in Table 3. High C18/C20 PUFA ratios were recorded in both species. The PUFA/SFA ratio of C. racemosa was 0.52 , whereas it was 0.15 for $U$. fasciata. Ratios based on the functional effects of FA were also calculated. For health, high fatty acid hypocholesterolemic/hypercholesterolemic $(\mathrm{h} / \mathrm{H})$ ratios are considered more beneficial as these are directly related to high PUFA content [26]. The atherogenic index (AI) and thrombogenic index (TI) are related to the protection against coronary 
artery diseases. The lower the value, the higher the protection properties [27]. C. racemosa exhibited lower $\mathrm{AI}$ and $\mathrm{TI}$ and higher $\mathrm{h} / \mathrm{H}$ than $U$. fasciata.

Table 2. Fatty acids (\% of total fatty acids (TFAs)) of Caulerpa racemosa and Ulva fasciata.

\begin{tabular}{|c|c|c|}
\hline Fatty Acid & C. racemosa $(\%)$ & U. fasciata (\%) \\
\hline C4:0 (Butyric) & $5.3 \pm 0.3$ & $0.8 \pm 0.0$ \\
\hline C6:0 (Caproic) & $0.2 \pm 0.0$ & / \\
\hline C11:0 (Undecanoic) & $0.1 \pm 0.1$ & / \\
\hline C12:0 (Lauric) & $1.2 \pm 0.0$ & $0.1 \pm 0.0$ \\
\hline C13:0 (Tridecanoic) & $0.3 \pm 0.0$ & l \\
\hline C14:0 (Myristic) & $0.6 \pm 0.1$ & $1.7 \pm 0.0$ \\
\hline C15:0 (Pentadecanoic) & $0.4 \pm 0.0$ & $0.2 \pm 0.0$ \\
\hline C16:0 (Palmitic) & $27.6 \pm 0.6$ & $59.9 \pm 0.5$ \\
\hline C17:0 (Heptadecanoic) & $0.3 \pm 0.2$ & $0.2 \pm 0.0$ \\
\hline C18:0 (Stearic) & $3.3 \pm 0.0$ & $3.2 \pm 0.0$ \\
\hline C20:0 (Arachidic) & $0.4 \pm 0.0$ & $0.2 \pm 0.0$ \\
\hline C21:0 (Heneicosanoic) & $0.1 \pm 0.0$ & $0.2 \pm 0.0$ \\
\hline C22:0 (Behenic) & $1.00 \pm 0.1$ & $0.9 \pm 0.0$ \\
\hline C23:0 (Tricosanoic) & $0.3 \pm 0.0$ & nd \\
\hline C24:0 (Lignoceric) & $0.1 \pm 0.0$ & $4.6 \pm 0.1$ \\
\hline Total SFAs & $41.3 \pm 0.4$ & $72.1 \pm 0.4$ \\
\hline C15:1 & $0.5 \pm 0.0$ & / \\
\hline C16:1 (Palmitoleic) & $4.5 \pm 0.1$ & $3.0 \pm 0.0$ \\
\hline $\mathrm{C} 17: 1$ & $1.0 \pm 0.5$ & $0.1 \pm 0.0$ \\
\hline C18:1w9 (Oleic) & $28.1 \pm 0.0$ & $5.9 \pm 0.0$ \\
\hline C20:1w9 (cis-11-Eicosenoic) & $0.4 \pm 0.5$ & $0.7 \pm 0.0$ \\
\hline C22:1w9 (Erucic) & nd & $1.7 \pm 0.5$ \\
\hline C24:1w9 (Nervonic) & $0.2 \pm 0.0$ & $1.2 \pm 0.0$ \\
\hline Total MUFAs & $34.6 \pm 0.7$ & $12.7 \pm 0.5$ \\
\hline C18:2w6 (Linoleic) & $9.0 \pm 0.1$ & $5.3 \pm 0.0$ \\
\hline C18:3w6 \& $\omega 3$ ( $\gamma \& \alpha$-Linolenic $)$ & $7.2 \pm 0.1$ & $4.0 \pm 0.0$ \\
\hline C20:2w6 (cis-Eicosadienoic) & $0.6 \pm 0.0$ & $0.4 \pm 0.0$ \\
\hline $\begin{array}{c}\text { C20:3w6 \& } \omega 33 \\
\text { (cis-Eicosatrienoic) }\end{array}$ & $1.2 \pm 0.0$ & $0.3 \pm 0.0$ \\
\hline C20:4w6 (Arachidonic) & $0.7 \pm 0.0$ & $0.4 \pm 0.0$ \\
\hline C20:5w3 (cis-Eicosapentaenoic) & $0.7 \pm 0.6$ & / \\
\hline C22:2w6 (cis-Docosadienoic) & $0.4 \pm 0.0$ & nd \\
\hline C22:6w3 (cis-Docosahexanoic) & $1.8 \pm 0.0$ & nd \\
\hline Total PUFAs & $21.6 \pm 0.2$ & $10.5 \pm 0.0$ \\
\hline Unidentified & 2.5 & 4.7 \\
\hline
\end{tabular}

Average reference values $(\%$ TFAs \pm SD); TFAs = total fatty acids; SD = standard deviation; nd = not detected; I = detected at less than $0.1 \%$. SFAs = saturated fatty acids; MUFAs = monounsaturated fatty acids;

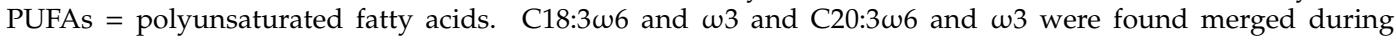
GC analysis.

Table 3. Nutritional quality indexes of fatty acids from Caulerpa racemosa and Ulva fasciata.

\begin{tabular}{cccccccc}
\hline Seaweed & $\mathbf{C 1 8 / C 2 0}$ & $\mathbf{\omega 6} / \mathbf{\omega 3}$ & AI & TI & h/H & PUFA/SFA & UI \\
\hline C. racemosa & 4.99 & $0.97-7.54$ & 0.56 & $0.56-0.91$ & $1.36-1.62$ & 0.52 & 97 \\
U. fasciata & 8.03 & $1.39-120.40$ & 2.89 & $2.78-5.48$ & $0.19-0.25$ & 0.15 & 39 \\
\hline
\end{tabular}

$\mathrm{AI}=$ atherogenic index; $\mathrm{TI}=$ thrombogenic index; $\mathrm{h} / \mathrm{H}=$ fatty acid hypocholesterolemic/hypercholesterolemic ratio; PUFA = polyunsaturated fatty acid; SFA = saturated fatty acid; UI = unsaturation index.

\subsection{Monosaccharide Composition Analysis}

The unit sugar composition of purified fractions of $C$. racemosa and ulvans of $U$. fasciata was determined by high-performance anion-exchange chromatography (HPAEC). The results were expressed as a percentage of sugars relative to the total monosaccharides detected. Eleven 
monosaccharides were identified in the HWE fraction from C. racemosa. The main contents were glucose $(52.4 \%)$, galactose $(15.6 \%)$, mannose $(12.6 \%)$, and xylose $(8.2 \%)$; lower amounts of fructose $(4.0 \%)$, glucuronic acid $(1.4 \%)$, fucose $(1.3 \%)$, and rhamnose $(1.0 \%)$ were found; and there were trace amounts of arabinose, glucosamine, and glucoheptose. Meanwhile, there were seven monosaccharides identified in crude ulvan extracted from Ulva fasciata, characterized by high amounts of rhamnose $(54 \%)$ and glucose $(26.6 \%)$ and lower amounts of xylose $(7.8 \%)$ and glucuronic acid $(1.3 \%)$. The total monosaccharide contents were $198.13 \pm 8.23 \mu \mathrm{g} \mathrm{mg}^{-1}$ of $\mathrm{dw}$ for $\mathrm{HWE}$ and $62.27 \pm 1.6 \mu \mathrm{g} \mathrm{mg} \mathrm{of} \mathrm{dw}^{-1}$ for crude ulvan (Table 4).

Table 4. Monosaccharide composition as a percentage of total sugars and total content of sugars $\left(\mu \mathrm{g} \mathrm{mg} \mathrm{g}^{-1} \mathrm{dw}\right)$ in hot water extract (HWE) from Caulerpa racemosa and crude ulvan from Ulva fasciata.

\begin{tabular}{|c|c|c|}
\hline & C. racemosa $\mathrm{HWE}$ & U. fasciata Crude Ulvan \\
\hline Monosaccharide & \multicolumn{2}{|c|}{$\%$ of Total Sugars } \\
\hline Fucose & $1.30 \pm 0.05$ & / \\
\hline Rhamnose & $1.07 \pm 0.05$ & $53.98 \pm 1.5$ \\
\hline Arabinose & $0.29 \pm 0.01$ & 1 \\
\hline Glucosamine & $0.95 \pm 0.04$ & / \\
\hline Galactose & $15.62 \pm 0.3$ & $0.68 \pm 0.01$ \\
\hline Glucose & $52.42 \pm 1.3$ & $26.64 \pm 0.7$ \\
\hline Mannose & $12.61 \pm 0.1$ & / \\
\hline Xylose & $8.21 \pm 0.1$ & $7.85 \pm 0.2$ \\
\hline Fructose & $4.09 \pm 0.7$ & / \\
\hline Glucoheptose & $0.26 \pm 0.01$ & $0.51 \pm 0.02$ \\
\hline Glucuronic acid & $1.43 \pm 0.02$ & $1.38 \pm 0.03$ \\
\hline Others & $1.75 \pm 0.07$ & $8.96 \pm 2.5$ \\
\hline Total $\left(\mu \mathrm{g} \mathrm{mg}{ }^{-1} \mathrm{dw}\right)$ & $198.13 \pm 8.23$ & $62.27 \pm 1.61$ \\
\hline
\end{tabular}

Others represents the sum of non-identified monosaccharides; / = not detected. Data are means \pm SD $(n=2)$. $\mathrm{SD}=$ standard deviation.

\subsection{Fourier-Transform Infrared (FTIR) Spectroscopy}

The FTIR spectra and spectral bands of interest of C. racemosa (HWE) and crude ulvan from U. fasciata are shown in Figure 1.

The IR spectrum of HWE and crude ulvan within the $2000-500 \mathrm{~cm}^{-1}$ zone or the fingerprint region for polysaccharides were used for data analysis. HWE showed spectral bands of high intensity at 1232 and $1022 \mathrm{~cm}^{-1}$, while bands of medium or low intensity were at 1637,1560 , and $871 \mathrm{~cm}^{-1}$. All spectral bands between 1260 and $1220 \mathrm{~cm}^{-1}$ related to the sulfation level in general [28,29]. The spectral bands at $1240-1230 \mathrm{~cm}^{-1}$ and $1022 \mathrm{~cm}^{-1}$ in HWE from C. racemosa were due to stretching of $-\mathrm{SO}_{3}$ and C-O in ring groups [30,31]. The medium and weak intensity bands at $1640-1630 \mathrm{~cm}^{-1}$ in HWE were due to carboxylic acid vibrations. The peaks at the $1561-1546 \mathrm{~cm}^{-1}$ bands in HWE indicate amide N-H bending vibrations [30]. The band at $871 \mathrm{~cm}^{-1}$ in HWE is characteristic of the presence of sulfate groups on the molecule $[30,32,33]$.

Crude ulvan has specific spectral bands of high intensity at 1612,1033 , and $979 \mathrm{~cm}^{-1}$ and bands of medium or low intensity at 1420, 1198, 980,928, 848, and $790 \mathrm{~cm}^{-1}$.

Strong- and weak-intensity carboxylic vibrations were found around 1612 and $1420 \mathrm{~cm}^{-1}$. The strong intensity at around $1612 \mathrm{~cm}^{-1}$ corresponded to an asymmetrical stretching band attributed to the presence of $\mathrm{OH}$ groups, which is within the spectral bands of uronic acids [34]. The weaker intensity band at around $1420 \mathrm{~cm}^{-1}$ was symmetric stretching vibration of carboxylic groups [35]. Between 1200 and $1000 \mathrm{~cm}^{-1}$, the region was dominated by sugar ring vibrations that overlapped stretching vibrations of $\mathrm{C}-\mathrm{OH}$ side groups and the $\mathrm{C}-\mathrm{O}-\mathrm{C}$ glycosidic bond vibrations. The double spectral band at $1198 \mathrm{~cm}^{-1}$ indicates the presence of sulfate groups that belongs to a band indicating $\mathrm{S}=\mathrm{O}$ elongation bonding. The band at $1033 \mathrm{~cm}^{-1}$ had the highest intensity, corresponding to a C-O-S elongation in the equatorial position [36]. The bands around $980 \mathrm{~cm}^{-1}$ correspond to glycosidic 
linkages [36,37] or are associated with galactose-6-sulfate [37]. The bands around $848 \mathrm{~cm}^{-1}$ are characteristic of the presence of sulfate groups on the molecule.

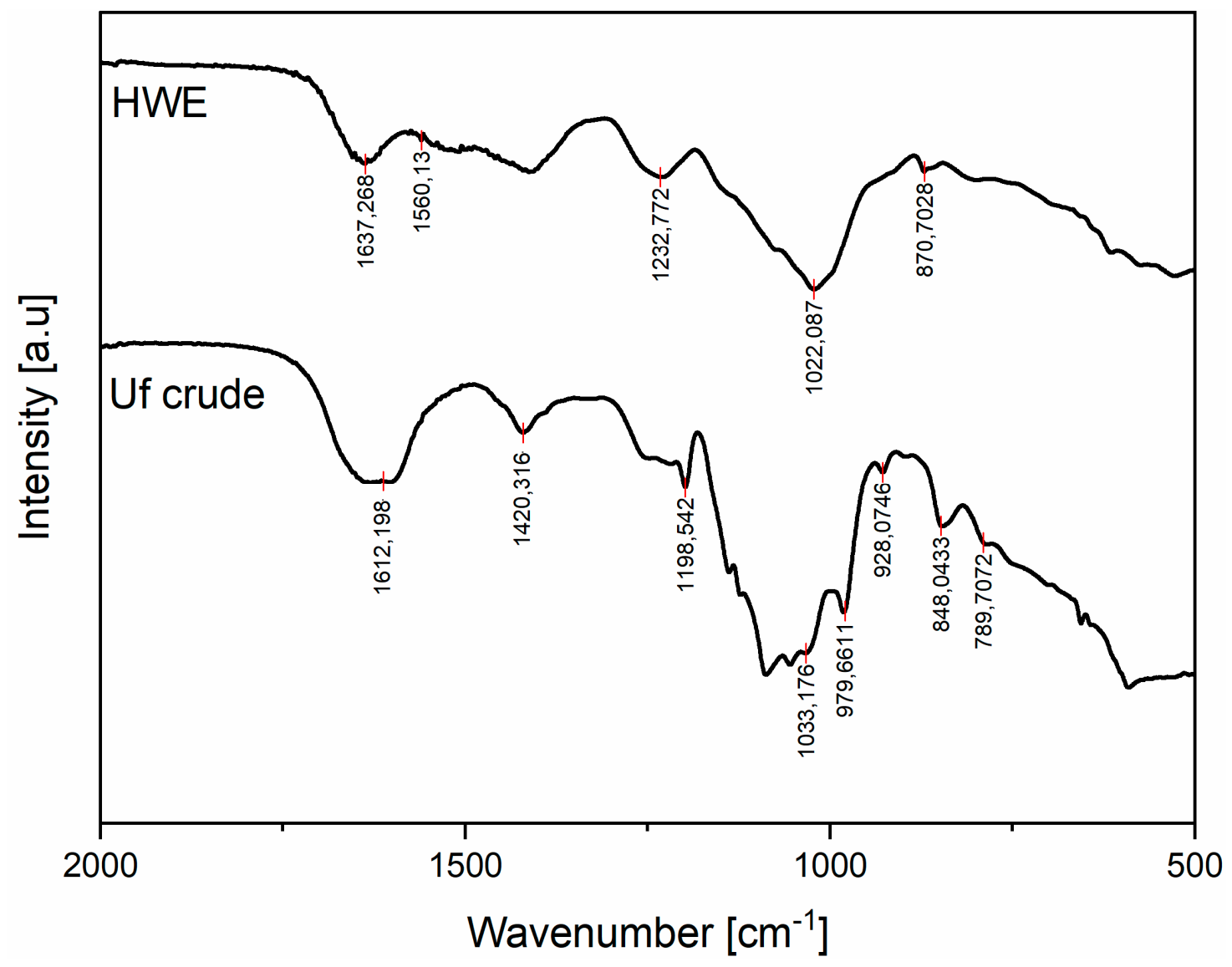

Figure 1. FTIR spectra of $C$. racemosa (HWE) and $U$. fasciata (crude ulvan) fractions.

\subsection{Amino Acid Composition}

The amino acid composition of the raw seaweeds Caulerpa racemosa and Ulva fasciata was established using gas chromatography and is presented in Table 5. The amino acid composition of ovalbumin, a reference protein from the egg white, is also shown in Table 5 for comparison. Amino acids have been classified according to their quality as essential (EAAs) or non-essential (NEAAs) amino acids. Leucine $(9.64 \pm 0.09 \%)$, valine $(8.63 \pm 0.02 \%)$, isoleucine $(6.14 \pm 0.10 \%)$, and lysine $(5.96 \pm 0.14 \%)$ are the most represented EAAs in C. racemosa. U. fasciata is rich in the EAAs leucine $(9.31 \pm 0.28 \%)$, valine $(8.50 \pm 0.07 \%)$, lysine $(7.92 \pm 0.44 \%)$, and phenylalanine $(6.07 \pm 0.35 \%)$. Both macroalgae are deficient in the EAAs histidine and methionine $(<2.50 \%$ in C. racemosa and $<1.5 \%$ in $U$. fasciata). High glutamic acid and aspartic acid (NEAAs) contents have been observed in both algae $(18.70 \pm 0.17 \%$ and $15.49 \pm 0.14 \%$ glutamic acid content for C. racemosa and $U$. fasciata, respectively; $11.53 \pm 0.11 \%$ and $10.95 \pm 0.46 \%$ aspartic acid content for $C$. racemosa and $U$. fasciata, respectively). The EAA/NEAA ratio has been calculated for both algae. This value, which indicates of the quality of proteins, must tend towards or be greater than 1 in order to contribute to an optimal EAA intake. Observed EAA/NEAA ratios were $0.83 \pm 0.00$ in C. racemosa, and $0.73 \pm 0.04$ in U. fasciata.

\subsection{Minerals}

Major mineral elements $(\mathrm{Ca}, \mathrm{Mg}, \mathrm{Na}$, and $\mathrm{K}$ ) and trace elements ( $\mathrm{Fe}, \mathrm{Zn}, \mathrm{Cu}$, and $\mathrm{Mn}$ ) were determined using a PerkinElmer AAnalyst 200 atomic absorption spectrophotometer (AAS) with a single hollow cathode lamp for each element and an air-acetylene burner. 
The mineral contents expressed as the content of each mineral relative to the seaweed dry weight (\% of dw) of C. racemosa and U. fasciata are given in Table 6. The percentages of the recommended daily intake covered by an intake of $8 \mathrm{~g}$ of dry seaweed are also presented, as is the daily recommended intake allowance [9]. C. racemosa had a high total macroelement content (16.83\% dw); sodium had the highest content $(7.48 \%)$, followed by potassium $(5.30 \%)$, calcium $(3.55 \%)$, and magnesium $(0.5 \%)$. Microelement content was also high (1.03\% of algal dw) and included iron $(0.49 \%)$, zinc $(0.42 \%)$, copper $(0.11 \%)$, and manganese $(0.006 \%)$. U. fasciata was rich in macroelements, presenting a total of $12.49 \%$ of algal dw; calcium had the highest content (4.80\%), followed by sodium (4.71\%), magnesium (2.24\%), and potassium (1.51\%). Microelements accounted for $2.10 \%$ of algal dw and were represented by iron $(1.77 \%)$, zinc $(0.27 \%)$, copper $(0.06 \%)$, and manganese $(0.003 \%)$. Eating $8 \mathrm{~g}$ of dry C. racemosa represents between $8.7 \%$ and $653.3 \%$ of the recommended daily intake for minerals. These percentages were high, especially for the microelements. For U. fasciata, $8 \mathrm{~g}$ of dry seaweed covered $2360 \%$ of the recommended daily intake (RDI) of iron. The $\mathrm{Na} / \mathrm{K}$ ratios in C. racemosa and $U$. fasciata were 1.41 and 3.12 , respectively.

Table 5. Amino acid compositions of Caulerpa racemosa and Ulva fasciata expressed as a percentage (\%) of the total amino acids detected by gas chromatography.

\begin{tabular}{|c|c|c|c|c|}
\hline & & $\begin{array}{c}\text { C. racemosa }(\% \text { of } \\
\text { Total AAs) }\end{array}$ & $\begin{array}{l}\text { U. fasciata }(\% \text { of } \\
\text { Total AAs) }\end{array}$ & $\begin{array}{c}\text { Ovalbumin a }(\% \\
\text { of Total AAs) }\end{array}$ \\
\hline \multirow{7}{*}{$\begin{array}{l}\text { Essential Amino } \\
\text { Acids (EAAs) }\end{array}$} & Threonine & $4.27 \pm 0.10$ & $3.12 \pm 0.13$ & 3.95 \\
\hline & Valine & $8.63 \pm 0.02$ & $8.50 \pm 0.07$ & 7.10 \\
\hline & Lysine & $5.96 \pm 0.14$ & $7.92 \pm 0.44$ & 10.14 \\
\hline & Isoleucine & $6.14 \pm 0.10$ & $4.98 \pm 0.17$ & 6.32 \\
\hline & Leucine & $9.64 \pm 0.09$ & $9.31 \pm 0.28$ & 8.16 \\
\hline & Phenylalanine & $5.79 \pm 0.07$ & $6.07 \pm 0.35$ & 5.39 \\
\hline & Histidine & $2.41 \pm 0.00$ & $1.41 \pm 0.08$ & 5.39 \\
\hline \multirow{12}{*}{$\begin{array}{l}\text { Non-Essential Amino } \\
\text { Acids (NEAAs) }\end{array}$} & Methionine & $2.37 \pm 0.07$ & $0.86 \pm 0.20$ & 4.08 \\
\hline & Total EAAs & $45.28 \pm 0.12$ & $42.17 \pm 1.31$ & 50.52 \\
\hline & Aspartic acid & $11.53 \pm 0.11$ & $10.95 \pm 0.46$ & 8.16 \\
\hline & Serine & $3.54 \pm 0.07$ & $3.11 \pm 0.46$ & 8.95 \\
\hline & Glutamic acid & $18.70 \pm 0.17$ & $15.49 \pm 0.14$ & 13.03 \\
\hline & Glycine & $5.66 \pm 0.04$ & $6.87 \pm 0.16$ & 4.47 \\
\hline & Alanine & $7.42 \pm 0.12$ & $10.85 \pm 0.52$ & 8.82 \\
\hline & Tyrosine & $3.09 \pm 0.14$ & $4.04 \pm 0.08$ & 2.37 \\
\hline & Proline & $4.39 \pm 0.07$ & $5.13 \pm 0.07$ & 3.69 \\
\hline & Hydroxyproline & $0.39 \pm 0.05$ & $1.39 \pm 0.00$ & ND \\
\hline & Total NEAAs & $54.72 \pm 0.12$ & $57.83 \pm 1.31$ & 49.48 \\
\hline & EAA/NEAA ratio & $0.83 \pm 0.00$ & $0.73 \pm 0.04$ & 1.02 \\
\hline
\end{tabular}

Values presented for C. racemosa and U fasciata are means of duplicates \pm SD. ${ }^{\text {a }}$ Values for the ovalbumin composition in amino acids were adapted from Kazir et al. [38].

Table 6. Composition of macroelements and microelements (\% of algal $\mathrm{dw}$ ), recommended daily intakes, and recommended daily allowances of C. racemosa and $U$. fasciata.

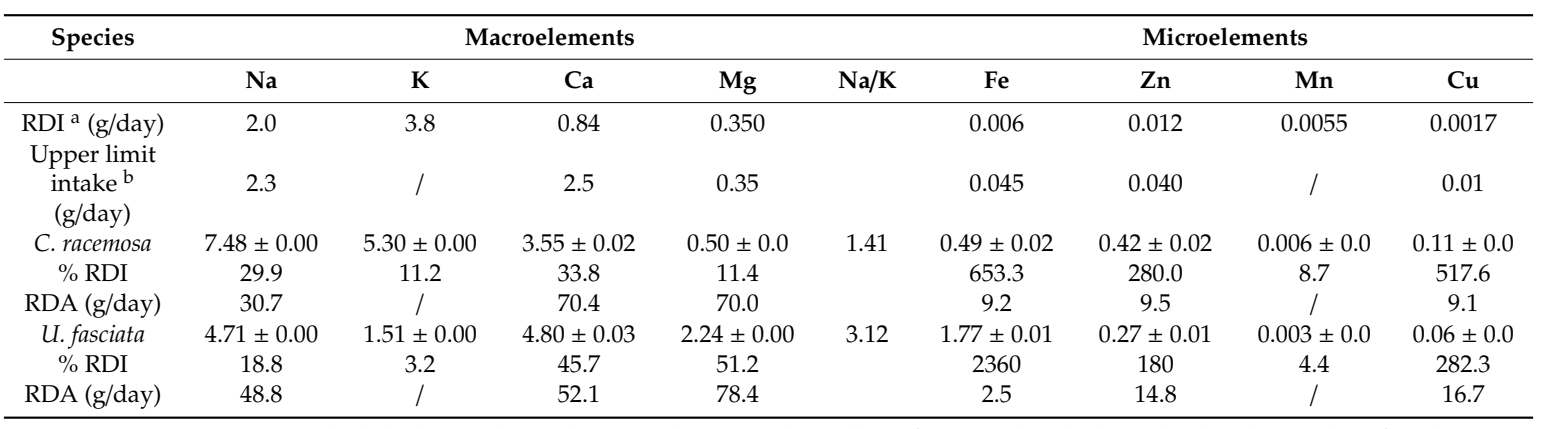

${ }^{\text {a }}$ RDI = Recommended daily intake and upper limit intake values for a male adult with a bodyweight of $70 \mathrm{~kg}$ according to the World Health Organization (2002); ${ }^{b}$ Upper limit intake according to National Health and Medical Research Council (2006); \% RDI is based on a daily intake of $8 \mathrm{~g}$ dry weight of seaweed; RDA = recommended daily allowance. Data are means $\pm \mathrm{SD}(n=2)$. $\mathrm{SD}=$ standard deviation. 


\subsection{Pigments}

Pigment analysis was based on the method used by Silkina et al. [39] with some modifications. The analysis was performed by high-performance liquid chromatography (HPLC) on a Nucleodur C18 column (EC 250/4.6 100-5 C18ec Macherey-Nagel). A two-solvent elution (solvent A 100\% 0-27 min, solvent B $100 \%$ 27-42 $\mathrm{min}$ ) was used at a flow rate of $1.4 \mathrm{~mL} / \mathrm{min}$ to separate the pigments. Pigment extraction from raw material $(20 \mathrm{mg})$ was diluted with methanol $\left(2 \mathrm{~mL}\right.$, at $\left.4{ }^{\circ} \mathrm{C}\right)$ and was sonicated (pulse 2, amplitude 100) for $2 \mathrm{~min}$ in test tubes. Samples were kept in the darkroom $\left(4^{\circ} \mathrm{C}, 24 \mathrm{~h}\right)$, centrifuged $(36,000 \times g, 4 \mathrm{~min})$ and then filtered $(0.22 \mu \mathrm{m}$, Minisart High Flow, Sartorius Stedim Biotech, Göttingen, Germany) before analysis.

Determinations of pigment composition are shown in Table 7. In this study, chlorophyll $a$ and $b$ and $\beta$-carotene were detected in both seaweeds. Chlorophyll $b$ was the major pigment in both seaweeds, representing $81.42 \pm 0.24 \mathrm{mg} / \mathrm{g}$ of $\mathrm{dw}$ for C. racemosa and $4.64 \pm 0.60 \mathrm{mg} / \mathrm{g}$ of $\mathrm{dw}$ for $U$. fasciata. C. racemosa contained more pigments than $U$. fasciata. Total pigment content of $C$. racemosa $(140.84 \pm 2.33 \mathrm{mg} / \mathrm{g} \mathrm{dw})$ was almost 20 times higher than that of $U$. fasciata $(7.54 \pm 1.34 \mathrm{mg} / \mathrm{g} \mathrm{dw})$.

Table 7. Pigment contents (mg/g dw) of Caulerpa racemosa and Ulva fasciata.

\begin{tabular}{cccccc}
\hline Seaweeds & Chlorophyll $\boldsymbol{a}$ & Chlorophyll $\boldsymbol{b}$ & $\boldsymbol{\beta}$-Carotene & Total Chlorophyll & Total Pigments \\
\hline C. racemosa & $42.15 \pm 0.21$ & $81.42 \pm 0.24$ & $17.26 \pm 1.88$ & 123.58 & 140.84 \\
U. fasciata & $2.18 \pm 0.74$ & $4.64 \pm 0.60$ & $0.72 \pm 0.00$ & 6.82 & 7.54 \\
\hline
\end{tabular}

Data are means $\pm \mathrm{SD}(n=2) . \mathrm{SD}=$ standard deviation.

\subsection{Evaluation of Cytotoxicity and Antiviral and Antioxidant Activities}

After three days of treatment, microscopically visible alteration of normal cell morphology was observed, and the availability assay showed destruction of the cell layer. No cytotoxic effect of polysaccharides on the Vero cells was observed in the range of the concentrations assayed. No anti-HSV activity was detected for the crude ulvan. However, the hot water extract (HWE) fraction of C. racemosa showed antiherpetic activity with an $\mathrm{EC}_{50}$ of $85.59 \pm 26.27 \mu \mathrm{g} / \mathrm{mL}$ (Table 8 ). Cellular protection of $70 \%$ was obtained for $200.0 \mu \mathrm{g} / \mathrm{mL} 72 \mathrm{~h}$ after infection. The free radical scavenging of the blank and the fractions of HWE and crude ulvan were estimated by the decrease in absorbance due to the reduction of the DPPH radical by the extracts. The BHA and BHT standards presented inhibiting concentrations $\left(\mathrm{IC}_{50}\right)$ of $7.05 \pm 0.59$ and $5.32 \pm 0.59 \mu \mathrm{g} / \mathrm{mL}$, respectively. The HWE had 57.16\% maximum scavenging activity at $5 \mathrm{mg} / \mathrm{mL}$, while crude ulvan had $15.61 \%$ at $50 \mathrm{mg} / \mathrm{mL}$. Samples of HWE and crude ulvan had weak antiradical effects in the concentration range used, with $\mathrm{IC}_{50}$ values of 276.08 and $4482.49 \mu \mathrm{g} / \mathrm{mL}$, respectively.

Table 8. Evaluation of cytotoxicity and antiviral and antioxidant activities of polysaccharide fractions.

\begin{tabular}{cccc}
\hline Samples & $\mathrm{CC}_{\mathbf{5 0}}(\mu \mathrm{g} / \mathrm{mL})$ & $\mathrm{EC}_{\mathbf{5 0}}(\mu \mathrm{g} / \mathrm{mL})$ & $\mathrm{IC}_{\mathbf{5 0}}(\mu \mathrm{g} / \mathrm{mL})$ \\
\hline HWE & $>200.00$ & $85.59 \pm 26.27$ & $276.08 \pm 52.62$ \\
Zovirax & $>200.00$ & $0.47 \pm 0.07$ & \\
Crude ulvan & $>200.00$ & $>200.00$ & $4482.49 \pm 635.05$ \\
Zovirax & $>200.00$ & $0.37 \pm 0.03$ & \\
BHA & & & $7.05 \pm 0.59$ \\
BHT & & & $5.32 \pm 0.59$
\end{tabular}

The $50 \%$ cytotoxic concentration $\left(\mathrm{CC}_{50}\right)$ is the concentration that reduced the absorbance of mock-infected cells to $50 \%$ of that of controls. The $50 \%$ antiviral effective concentration $\left(\mathrm{EC}_{50}\right)$ is the concentration that achieved $50 \%$ protection of virus-infected cells from the HSV-induced destruction. The $50 \%$ inhibitory concentration $\left(\mathrm{IC}_{50}\right)$ is the concentration sufficient to obtain $50 \%$ of a maximum scavenging capacity. BHA = butylated hydroxyanisole; BHT = butylated hydroxytoluene. 


\section{Discussion}

The biochemical composition of Caulerpa racemosa collected in the Philippines agrees with previous studies of Caulerpa species in the Indo-Pacific regions [5,40]. In our study, C. racemosa protein content $(19.9 \pm 0.5 \%$ of dry weight) is within the concentration range (0.6-20.8\%) of the majority of edible Caulerpa [5]. Osuna-Ruiz et al. [41] reported lower mean values of proteins (11.96\%) and lipids (0.92\%) from C. sertularioides collected in Sinaloa, Mexico. However, its reported ash content (35.54\%) was higher than that found in the present study of C. racemosa. In terms of biochemical composition from polysaccharides extracts, Ji et al. [42] reported comparable protein contents $(9.9 \%, 14.0 \%$, and $2.0 \%)$ from C. racemosa extracted by neutral protease combined with hot water, compared to that of the HWE fraction $(8.8 \%)$ of the present study. Meanwhile, the uronics content (3.9-7.9\%) and sulfates content (27.6-48.3\%) that they reported were higher than those of the HWE in the present study $(1.6 \%$ and $10.54 \%$, respectively). In general, total sugars were abundant components compared to proteins, phenols, and flavonoids [43], as was also observed for neutral sugars for HWE in the present study. On the contrary, another study by Hao et al. [43] on C. racemosa var. peltata polysaccharides, extracted by hot water at $85^{\circ} \mathrm{C}$ for $3 \mathrm{~h}$, reported lower protein $(0.67 \%)$, polyphenols $(0.19 \%)$, and total sugar $(3.4 \%)$ contents [43] than the present HWE study.

The biochemical composition of Ulva fasciata in the present study is in agreement with previous studies for other Ulva species [44-46]. Yedukondala'Rao et al. [46] reported amounts of proteins $(25.15 \%)$, carbohydrates $(60.28 \%)$, and lipids $(9.15 \%)$ that were comparable to those of $U$. fasciata in the present study. However, Yedukondala Rao et al. [46] reported lower ash content (5.41\%) than that found in the present study of $U$. fasciata. Another study, considering tropical $U$. expansa from Sinaloa, Mexico, reported lower values of proteins $(4.12 \%)$ and lipids $(0.65 \%)$ but a higher value of ash (35.66\%) [41] when compared to the present study of $U$. fasciata. A significant seasonal variation of biochemical composition in green algae has been previously reported concerning species and geographic areas $[47,48]$. Ulva spp. have high protein content, although it may vary from place to place (5-30\% dw, according to Anh et al. [49]). For example, Ulva pertusa and Ulva intestinalis samples collected from Southern Thailand incorporate high contents of protein (14.6\% and $19.5 \%$ of $\mathrm{dw}$, respectively). Sulfates content $(3.12 \%)$ in the present study is within the range of values published in the literature $[35,50]$. Protein content $(8.0 \%)$ in the present study is much higher (by up to 20 times) than that found by Costa et al. [50] and is up to 2 times higher than that found by Hernández-Garibay et al. [35]. The uronic acid content (10.0\%) in the present study is higher than that found by Hernández-Garibay et al. [35].

The total amino acid composition profiles of C. racemosa are in accordance with previously reported data [5]. High amounts of the non-essential amino acids (NEAAs) aspartic acid and glutamic acid are found in both algae, with $11.53 \pm 0.11 \%$ and $18.70 \pm 0.17 \%$, respectively, in C. racemosa and $10.95 \pm 0.46 \%$ and $15.49 \pm 0.14 \%$, respectively, in $U$. fasciata. This profile follows previously published data, as the two amino acids generally represent between $26 \%$ to $32 \%$ of the total amino acid content [51]. These two amino acids are generally found in large quantities in seaweeds and are responsible for their characteristic "umami" taste and sensation [52]. The EAA/NEAA ratio of $0.83 \pm 0.00$, which is in the range of previously reported data $[5,43]$, indicates that C. racemosa is a balanced source of amino acids, close to ovalbumin (EAA/NEAA of 1.02). Given the total protein content and amino acid profile, this seaweed could be a good food resource to replace meat products. A lower EAA/NEAA ratio $(0.73 \pm 0.04)$ was observed for $U$. fasciata, which indicates that its consumption is less favorable for a good EAA intake. However, combining these two algae in the diet would lead to a complete supply of amino acids. The results concerning the content and the quality of the proteins in both algae must nevertheless be qualified, given the drying method used. It has been shown that solar and convective drying both involve in the destruction of amino acids in Ulva sp. (48.13 \pm 2.15 and $41.38 \pm 3.50 \mathrm{~g}$ EAA for $100 \mathrm{~g}$ of protein, respectively) when compared to vacuum drying $(56.71 \pm 1.91 \mathrm{~g}$ EAA for $100 \mathrm{~g}$ of protein) [53]. Therefore, the pretreatment of seaweeds should be carried out by other methods to preserve their quality. 
Macroalgae typically do not exceed $2-4.5 \%$ of $\mathrm{dw}$ as lipids, mainly as phospholipids and glycolipids $[18,54,55]$. The lipid content of Caulerpa and Ulva species can be high $(0.1-7.2 \%$ and $0.1-14.2 \%$ of $d w$, respectively), with a high content of PUFAs considered essential nutritional components in humans and animals. In the present study, we observed $4.5 \%$ of $\mathrm{dw}$ for C. racemosa and $4.1 \%$ of $\mathrm{dw}$ for $U$. fasciata in terms of lipids. The highest PUFA content was measured in C. racemosa, representing $60.8 \%$ of the total fatty acids. We observed a lower total PUFA content $(21.6 \%)$, but this was comparable to the PUFA content in C. racemosa var. laetevirens [5]. The most important PUFAs are the essential fatty acids eicosapentaenoic acid (EPA; C20:5 $\omega 3$ ) and docosahexaenoic acid (DHA; C22:6 $\omega$ 3) along with

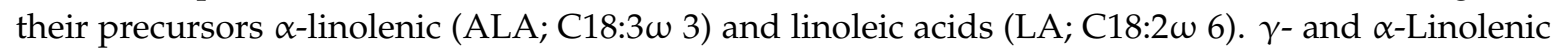
(C18:3 $\omega 6 \& \omega 3)$ and linoleic acids are the most abundant PUFAs in C. racemosa from the Philippines and are also present in $U$. fasciata according to the literature $[5,41]$. EPA, DHA, and arachidonic acid (C20:4w 6) are also present in C. racemosa, as described previously for other Caulerpa species [5,41]. Polyunsaturated fatty acids and carotenoids are most noteworthy as functional foods $[54,56]$. These are reported to have several health benefits, such as the prevention of skin scaling, hair loss, cardiovascular diseases, and cancer $[2,5,41,57]$. The FAO/WHO considered that a PUFA/SFA ratio below 0.45 is undesirable, as the SFAs potentially increase the blood cholesterol level [58]. Our present results in C. racemosa show potential properties complying with consumption requirements. For health, high $\mathrm{h} / \mathrm{H}$ ratios are considered more beneficial, as these are directly related to high PUFA content [26]. The results for $\mathrm{C}$. racemosa agree with $\mathrm{h} / \mathrm{H}$ values for marine fish like sardine or mackerel that are recognized as beneficial for health [59]. AI and TI are related to the protection against coronary artery diseases. The lower the value, the greater the protection properties [27]. The values of AI and TI for C. racemosa are in the range of reported Caulerpa species or lower than those of meat (1.08-1.58) and milk (2.1) [60]. Moreover, the $\omega 6 / \omega 3$ ratio $(<10)$ confirms the potential health benefits of the consumption of $C$. racemosa from the Philippines regarding the lipid distribution [61]. Concerning the nutritional quality indexes of fatty acids, U. fasciata cannot be defined as a potentially beneficial edible seaweed despite the presence of essential fatty acids. Indeed, the PUFA/SFA and h/H ratios are lower than the recommended values $[58,59]$ for a beneficial assessment. Moreover, $U$. fasciata is rich in long-chain SFAs (i.e., myristic, palmitic, and stearic acids), which are thrombogenic and promote platelet aggregation [62]. Although the $\omega 6 / \omega 3$ ratio for $U$. fasciata was $>10$, this value was attributed to PUFAs with $\mathrm{C} 18$ and not to the content of PUFAs with $\geq \mathrm{C} 20$. This $U$. fasciata species should still be considered a good-health promoter because of its considerable amount of C22:1 $\omega 9$ (erucic) and C24:1w9 (nervonic) acids, compounds which are said to prevent demyelinating disease [63].

Mineral content is one of the main nutritional characteristics of seaweeds taken up directly from their environment. Seaweeds absorb an incomparable wealth of mineral elements from the sea and are known as excellent sources of vitamins and minerals, especially potassium and iodine [19]. However, nutritional generalization of algal mineral content is difficult, mainly due to diversity arising from seasonality, geographic location, taxonomic variations, processing, and laboratory manipulations [18]. The total macroelement content of $C$. racemosa was higher $(16.83 \%)$ than that of $U$. fasciata $(12.49 \%)$ in the present study. Among the four macroelements tested, Na content was highest in both species, but the lowest was $\mathrm{Mg}$ in C. racemosa and $\mathrm{K}$ in $U$. fasciata. The differences in content are perhaps attributed to their morphological characteristics: C. racemosa is a stoloniferous plant with upright branches made up of ramuli and has higher capacity to absorb minerals in the surrounding water; in contrast, $U$. fasciata is a thin and membranous plant. Out of the microelements, Mn had the lowest content in both species, although in C. racemosa it was slightly higher.

Some macroelements of $\mathrm{C}$. racemosa, such as $\mathrm{Na}$ and $\mathrm{K}$, had higher values than those reported previously, while $\mathrm{Ca}$ and $\mathrm{Mg}$ were detected at similar levels compared to previous results in the same species $[5,64]$. The ratio of $\mathrm{Na} / \mathrm{K}$ in $\mathrm{C}$. racemosa from the Philippines was considered small $(<1.5)$; thus, consumption of this seaweed can help balance high-Na/K-ratio diets that are common today [65]. However, $\mathrm{Na} / \mathrm{K}$ ratios in the Caulerpa species were reported to be highly variable (0.3-2.3) depending on the methodology and the rinsing process [5]. The microelements in C. racemosa were all within the 
range of levels reported in previous studies $[5,64,66]$. Iron is essential for cell functions (oxygen and electron transport and DNA synthesis), while manganese helps in protein, lipid, and carbohydrate metabolism [67]. According to Garcia et al. [68], microelement concentrations vary with species, which could be due to morphological and physiological affinities for different metals. As the average daily consumption of dry seaweeds in Asia is $8 \mathrm{~g}$ and based on the results of the present study, the mineral contents of $C$. racemosa are within safe levels, giving it the potential to be a functional food for humans. For example, an $8 \mathrm{~g}$ portion of C. racemosa covered around $34 \%$ of the RDI of calcium, like other seaweeds, while the same quantity of cheddar cheese provides only $5 \%$ of the RDI $[32,69]$. In the Ulvophyceae, structurally diverse and heterogeneous sulfated polysaccharides [70] represent around $38-54 \%$ of $\mathrm{dw}$. The present study showed that the ash content of the $U$. fasciata was $23.3 \%$ of $d w$, representing a high mineral content. The macroelements of $U$. fasciata obtained in the present study were found to be higher than those found in previous studies $[64,66,68]$, with the exception of potassium, which was reported higher (3.77\%) [68] in different Ulva species. The $\mathrm{Na} / \mathrm{K}$ ratio in $U$. fasciata was 3.12 , which was higher than previous results. The microelement contents were also found to be higher than previous results [68], except for manganese (0.048\%) [66] and copper $(0.071 \%)$ [68], which were higher in previous results. Results of the daily recommended intake allowance showed that the use of no more than $2.5 \mathrm{~g}$ of $U$. fasciata would not compromise health due to the iron content of this seaweed. The accumulation of excess iron may generate oxidative stress and increase cardiovascular risk. However, the biological availability of minerals is influenced by diet composition, due to synergistic and antagonistic interactions [71]. Moreover, only $1-53 \%$ of iron from food is absorbed by the human body [72].

The significance of determining the micro- and macroelemental contents of seaweeds is related to their consumption by humans. It is a known fact that Asian countries, primarily Japan, China, and Korea and to a lesser extent the Philippines, Indonesia, and Malaysia are seaweed-eating countries $[65,73,74]$, and this has been associated with distinct health benefits, including cardioprotective, neuroprotective, and anti-inflammatory effects [75-77].

C. racemosa contained more pigments than $U$. fasciata. However, the two species demonstrated a high content of pigments and carotene, especially for C. racemosa. Although the amount of $\beta$-carotene for $C$. racemosa is low compared to chlorophyll a and b in the present study, it is still more than 40 times higher than that found in the study by Paul et al. [64] on the same species of C. racemosa. The amount of $\beta$-carotene previously reported for Ulva sp. $(0.031 \% \mathrm{of} \mathrm{dw})$ was much lower than that found for the present $U$. fasciata [54]. According to Paul et al. [64], the variation in the amount of pigments is comparable to fatty acids, as both are greatly affected by season and geographic location. Furthermore, $\beta$-carotene and other pigments in C. racemosa and $U$. fasciata vary as they are affected by time, season, cell growth, or plant location. Chlorophylls may also be used in human health; they can prevent cancer and have positive effects on inflammation and wound healing [54]. Studies carried out by Hsu et al. [78] have shown that chlorophylls directly act as reducers of free radicals and have the potential to protect lymphocytes against oxidative DNA damage by $\mathrm{H}_{2} \mathrm{O}_{2}$. Moreover, natural chlorophylls prevent lipid peroxidation of low-density lipoprotein (LDL). The second most important pigment is carotenoid, which is crucial due to its nutraceutical and antioxidative properties, especially in preventing pathologies caused by oxidative stress [79]. $\beta$-Carotene has anticancer properties and is absorbed ten times more easily by the body than its synthetic version [80]. Pigments from macroalgae are also important in the health food industry [19].

The sulfated cell-wall constituents may be classified into two of the three groups originally designated by Percival [81]: (a) sulfated xyloarabinogalactans and (b) sulfated glucuronoxylorhamnans and glucuronoxylorhamnogalactans. The sulfated xyloarabinogalactan group of cell-wall polysaccharides is present in Caulerpa [69,82]. Water-soluble heteropolysaccharides derived from Caulerpa racemosa are described as branched sulfated polymers containing 3-linked galactose, terminaland 4-linked xylose, and as 4- and 3,4-linked arabinose residues [32,69]. The sugar composition of the C. racemosa extract (HWE) in the present study is somewhat similar to the results of Ghosh et al. [32], 
who used the same method of extraction from C. racemosa collected in Western India and showed the presence of glucose, xylose, and galactose; smaller amounts of mannose; and traces of rhamnose, arabinose, and fucose. We obtained high percentages of glucose and galactose in HWE, which is in line with Ghosh et al. [32], and other dominant sugars such as mannose and xylose were also present. The ulvan backbone is most commonly composed of $\alpha$ - and $\beta$ - $(1,4)$-linked monosaccharides (rhamnose, xylose, glucuronic acids, and iduronic acids) with characteristic repeating disaccharide units [83]. Ulvans from $U$. armoricana [84] and $U$. rotundata [36] demonstrated that they consisted of rhamnose, glucose, xylose, glucuronic acids, and iduronic acids. These results showed that rhamnose was the dominant sugar, followed by sulfates and glucose. These sugars also indicate the presence of ulvans in the extracts. According to Lahaye and Robic [84], alcohol extraction decreased the content of minor sugars and glucose in the material. These small proportions of total sugar composition in all fractions in the present study could be attributed to the method of extraction used. The presence of glucose and other sugars in the present study indicates the presence of other types of saccharides besides ulvans. According to Lahaye and Robic [84], these other sugars are probably not in the form of free oligosaccharides since they were not removed during dialysis.

The IR spectrum of HWE confirmed the presence of sulfate ester, sugars, and proteins. Some C. racemosa extracts reported the presence of $\mathrm{N}-\mathrm{H}$ involved in metal adsorption binding processes [30,85]. This result is also similar in the study of Ghosh et al. [32]. The Si-C band can be attributed to observed silica particles or those attached to the thallus during collection, even after cleaning and drying of samples. A similar peak was reported in Sarada et al. [30] for Caulerpa fastigiata, where the presence of silica from diatomaceous earth in algal waste and composite material was determined. The asymmetrical stretching band attributed to the presence of OH groups, which is within the spectral bands of the uronic acids, was reported in a previous study for Ulva lactuca polysaccharide fractions [34]. These similar intensity bands were also found in the previous study for Ulva armoricana and Ulva rotundata fractions [36]. The presence of sulfate groups was also confirmed in the ulvan fraction by $\mathrm{S}=\mathrm{O}$ elongation, $\mathrm{C}-\mathrm{O}-\mathrm{S}$ elongation in the axial position, and C-O-S deformation in the equatorial position. According to Olasehinde et al. [34], the presence of sulfate groups in algal polysaccharides are correlated to their biological activities or are synthesized in the algal Golgi bodies. These bands are due to these sugar cycles, according to Robic et al. [36], and are a typical signal for ulvans [34-36,86]. The FTIR spectrum of $U$. fasciata crude ulvan extract confirmed the presence of sulfate groups and sugars. The presence, degree, and distribution of the sulfate groups are important in determining the biological activity of ulvan [86].

Viral infections count as the most predominant cause of death in humans worldwide. Marine seaweeds have proven to be a rich source for active antiviral metabolites. Polysaccharides extracted from seaweeds exhibit antiviral activity against a wide spectrum of viruses, including major human pathogenic agents such as human immunodeficiency virus (HIV), herpes simplex virus (HSV), vesicular stomatitis virus (VSV), and cytomegalovirus (CMV) [87-89]. Among the different deadly viruses, Herpesviridae, a large family, is responsible for a wide range of mild to severe infections in humans. The most notable herpes viruses belonging to Alphaherpesvirinae are herpes simplex virus type 1 (HSV-1) and herpes simplex virus type 2 (HSV-2), which have been widely studied. Typically, HSV-1 is associated frequently with orofacial infections and encephalitis. These viruses can establish persistent, long-term, latent infections in sensory neurons and cause lesions at the entry point of the human body. There is no definitive vaccine as yet against numerous prevalent viral infections, including herpes simplex viruses (HSV-1 and HSV-2). Additionally, these characteristic features of latency enhance the pathogenicity of HSV [89]. Kidgell et al. [83] reported that the antiviral activity of ulvan extends to different enveloped viruses of HSV, Newcastle disease, dengue, yellow fever, influenza, and measles virus $[83,90]$. In this study, the ulvan shows no activity in the concentration range tested (1 to $200 \mu \mathrm{g} / \mathrm{mL}$ ). However, according to the methodology used to evaluate the antiviral effects of ulvans against viral targets, the concentrations of ulvan required to inhibit viral yield by $50 \%$ are mixed, ranging from weak $\left(\mathrm{IC}_{50}>150 \mu \mathrm{g} / \mathrm{mL}\right)$ [91,92] to significant $\left(\mathrm{IC}_{50}=0.1-30 \mu \mathrm{g} / \mathrm{mL}\right)$ [93-95]. 
Variations in the antiviral activity of ulvan from different sources indicate a significant effect of structure. However, there are only a few studies that probe the antiviral activity of ulvan and, consequently, the understanding of its structure-activity relationship is restricted [83].

The hot water extract from $C$. racemosa showed antiherpetic activity, with an $\mathrm{EC}_{50}$ of $85.59 \pm 26.27 \mu \mathrm{g} / \mathrm{mL}$. The antiherpetic activity of HWE had previously been demonstrated by Ghosh et al. [32]. The hot water sulfated polysaccharide fraction isolated from Caulerpa racemosa collected in India was considered a selective inhibitor of thymidine kinase (TK) acyclovir-resistant HSV-1 strains in Vero cells with an $\mathrm{EC}_{50}$ of approximately $2.2-4.2 \mu \mathrm{g} / \mathrm{mL}$ [32]. The HWE studied by Ghosh et al. [32] appears to be more effective. The difference with antiherpetic activity can be explained not only by the monosaccharide composition, sulfate content, and geographical positions (India/Philippines), but also by the sensitivity of the methods used. While the extraction process is comparable, the HWE was evaluated for cytotoxicity on Vero cells using the MTT method, and the antiherpetic activity of HWE was determined by a plaque reduction assay against reference strains of HSV. Wang et al. [88] reported that sulfated polysaccharides from Caulerpa brachypus had antiviral activity against HSV-1 $\left(\mathrm{EC}_{50}=9.6 \mu \mathrm{g} / \mathrm{mL}\right)$. The authors showed that antiviral activity has a direct correlation with the degree of sulfation and the polysaccharide sugar units found (rhamnose, xylose, and glucose).

Viral infections are often caused by oxidative processes, favoring replication in infected cells, induction, and inhibition of cell proliferation [96]. In patients affected by herpes simplex, it was observed that an increase of the reactive oxygen species (ROS)-induced membrane phospholipid peroxidation caused dysfunction of vital cellular processes such as membrane transport and mitochondrial respiration. Antioxidants are effective in protecting living organisms against oxidative damages caused by ROS. Discovery and screening of antioxidant compounds with antiviral properties are promising since the treatment of viral diseases requires the suppression of viral replication and the promotion of cell survival. Hot water extract from C. racemosa showed antiviral and antioxidant activities. Several polysaccharides extracted from Caulerpa have shown antioxidant activities: the C. lentillifera polysaccharide produced by ultrasonic-assisted extraction presented good radical scavenging activities against the DPPH radical [97]. The $C$. lentillifera polysaccharide antioxidant activity might be influenced by sulfate and uronic acid contents [97]. Fernando et al. [33] reported DPPH activity, with an $\mathrm{IC}_{50}$ of $>2 \mathrm{mg} / \mathrm{mL}$, of a polysaccharide extracted from C. racemosa. The authors also suggested the influence of sulfate and polyphenol content. This sulfated polysaccharide had galactans and mannans from its major sugars $(15.36-32.71 \%$ of $\mathrm{dw})$. Galactans were also present in the C. racemosa fraction in the present study, which is in agreement with Fernando et al. [33].

The Caulerpa racemosa hot water extract showed great potential in human health development. Antiviral activities of antioxidants acting against viral infection can be exploited. However, various factors mentioned must be understood better; therefore, extracts from Caulerpa racemosa must be studied further with the investigation of the structure of sulfated polysaccharides and the determination antiviral and antioxidant mechanisms of action representing top priorities.

\section{Materials and Methods}

Caulerpa racemosa var. Forsskål and Ulva fasciata Delile were collected on August 15-16, 2017 (rainy season) along the coastal area of Barangay Lawigan ( $8.226^{\circ} \mathrm{N}$ and $\left.126.431^{\circ} \mathrm{E}\right)$, Bislig City, Surigao Del Sur, Philippines. The area has a $34 \%$ o salinity, a temperature of $27^{\circ} \mathrm{C}$, and a $\mathrm{pH}$ of 8.16 . Algae were immediately rinsed thoroughly with running fresh water to remove the remaining sand and epiphytes and left to dry under the shade, avoiding sunlight for 1 to 2 weeks. The dried samples (about $1 \mathrm{~kg}$ each) were then put in zip locks with corresponding labels (scientific name, date, place of collection, and other information pertinent to the seaweed) and finally transported to the LBCM in Vannes, France, where they were ground or cut into small pieces, freeze-dried, and stored in the dark for further analysis. 


\subsection{Biochemical Composition}

Protein, uronic acid, neutral sugar, sulfate group, and polyphenol contents: The biochemical composition of $C$. racemosa and $U$. fasciata were defined as percentages of each compound found in the total dry weight of raw material. All analyses were performed in triplicate. To characterize the seaweed, $10 \mathrm{mg}$ freeze-dried matter was mixed with $5 \mathrm{~mL}$ of $1 \mathrm{M} \mathrm{HCl}$ in a sealed vial at $100{ }^{\circ} \mathrm{C}$ for $2 \mathrm{~h}$, after which $5 \mathrm{~mL}$ of $1 \mathrm{M} \mathrm{NaOH}$ was added. The final solution was used to measure the protein, uronic acid, neutral sugar, and polyphenol contents. Neutral sugars were determined by the phenol-sulfuric acid colorimetric method, as described by Dubois [98], using anhydrous D-glucose (0-100 $\mu \mathrm{g} / \mathrm{mL})$ as the standard. The uronic acid content was quantified using the meta-hydroxydiphenyl (MHDP) method [99], with glucuronic acid as the standard $(0-100 \mu \mathrm{g} / \mathrm{mL})$. The bicinchoninic acid colorimetric (BCA) method [100] with a Micro BCA assay kit (ref. 23228, Thermo Scientific, Interchim, Montluçon, France) was used to measure the protein content. For the protein estimation, bovine serum albumin $(0-100 \mu \mathrm{g} / \mathrm{mL})$ was used as the standard. Polyphenols were quantified using the Folin-Ciocalteu method [101], using gallic acid as the reference. Water extraction was performed to measure the free sulfate group using the Azure A method [102]. For the extraction, $10 \mathrm{mg}$ freeze-dried seaweed was mixed with $5 \mathrm{~mL}$ of ultrapure water in a sealed vial at $100{ }^{\circ} \mathrm{C}$ for $2 \mathrm{~h}$, after which $5 \mathrm{~mL}$ of ultrapure water was added. For this estimation, sulfated dextran (17\%) (0-100 $\mathrm{gg} / \mathrm{mL})$ was used as the standard. Total ash was determined gravimetrically after the incineration of samples, followed by $2 \mathrm{~h}$ at $585^{\circ} \mathrm{C}$.

\subsection{Lipids and Fatty Acids}

Lipid extraction was performed following the method of Kendel et al. [103]. Lipid content was determined gravimetrically, and fatty acids were converted to fatty acid methyl ester (FAME). Finally, samples containing FAME were analyzed using a gas chromatography system coupled with flame ionization detection (GC-FID, TRACE 1300, Thermo-Fischer Scientific, Milan, Italy) and equipped with a capillary column CP-Sil 5 CB $(60 \mathrm{~m} \times 0.25 \mathrm{~mm} \times 0.25 \mu \mathrm{m})$; the carrier gas was nitrogen $(0.5 \mathrm{~mL} / \mathrm{min})$. The injector and detector were set at $250{ }^{\circ} \mathrm{C}$, and a temperature gradient was used for FAME analysis: the temperature was held at $170{ }^{\circ} \mathrm{C}$ for $4 \mathrm{~min}$ and programmed to $300^{\circ} \mathrm{C}$ at $4{ }^{\circ} \mathrm{C} / \mathrm{min}$. The FAs were identified by comparing the retention time with that of a commercial mixture (Supelco 37 Component FAME Mix, ThermoScientific, Illkirch, France). The relative proportions of the individual acids were calculated by the ratio of their peak area and expressed as percentages of total fatty acids.

\subsection{Nutritional Quality Indexes}

The nutritional quality indexes were assessed according to different parameters calculated with the concentration of fatty acids. For all calculations needing a distinction between $\mathrm{C} 18: 3 \omega 6$ and $\omega 3$ and C20:3w6 and $\omega 3$, the calculations were done in two ways. The first one considered all the percentages as $\omega 6$, and the second one considered all the percentages as $\omega 3$.

(1) C18/C20 PUFA Ratio:

$$
\frac{\mathrm{C} 18}{\mathrm{C} 20}=\frac{\sum \mathrm{C} 18 \mathrm{PUFA}}{\sum \mathrm{C} 20 \mathrm{PUFA}}
$$

(2) $\omega 6 / \omega 3$ Ratio:

$$
\omega 6 / \omega 3=\frac{\sum \text { PUFA } \omega 6}{\sum \text { PUFA } \omega 3}
$$

(3) Atherogenicity Index (AI) [26]:

$$
\mathrm{AI}=\frac{\mathrm{C} 12: 0+4 \times \mathrm{C} 14: 0+\mathrm{C} 16: 0}{\sum \mathrm{MUFA}+\sum \text { PUFA } \omega 6+\sum \text { PUFA } \omega 3}
$$

(4) Thrombogenicity Index (TI): 


$$
\mathrm{TI}=\frac{\mathrm{C} 14: 0+\mathrm{C} 16: 0+\mathrm{C} 18: 0}{0.5 \times \sum \text { MUFA }+0.5 \times \sum \text { PUFA } \omega 6+3 \times \sum \text { PUFA } \omega 3+\frac{\sum \text { PUFA } \omega 3}{\sum \text { PUFA } \omega 6}}
$$

(5) Hypocholesterolemic/Hypercholesterolemic $(\mathrm{h} / \mathrm{H})$ Fatty Acids:

(6) PUFAs/SFAs:

$$
\mathrm{h} / \mathrm{H}=\frac{\mathrm{C} 18: 1 \omega 9+\mathrm{C} 18: 2 \omega 6+\mathrm{C} 20: 4 \omega 6+\mathrm{C} 18: 3 \omega 3+\mathrm{C} 20: 5 \omega 3}{\mathrm{C} 14: 0+\mathrm{C} 16: 0}
$$

$$
\text { PUFA } / \text { SFA }=\frac{\sum \text { PUFA }}{\sum \text { SFA }}
$$

where PUFAs represents polyunsaturated fatty acids, MUFAs represents monounsaturated fatty acids, and SFA represents saturated fatty acids.

Unsaturation index (UI) was calculated by multiplying the number of double bonds by the percentage of each fatty acid, followed by summing up their contributions [104].

\subsection{Cell Wall Polysaccharides}

Ground freeze-dried samples were extracted sequentially with $96 \%$ ethanol, chloroform/methanol $(1: 1, v / v)$, and acetone in a Soxhlet apparatus before polysaccharide extraction. The depigmented samples ( $4 \mathrm{~g}$ ) from $\mathrm{C}$. racemosa were extracted following the method of Ghosh et al. [32] with distilled water (200 mL, pH 6.5) at $80^{\circ} \mathrm{C}$ for $30 \mathrm{~min}$, three times (hot water extracted (HWE)); extracts were dialyzed extensively against distilled water using a membrane having molecular weight cutoff of $12 \mathrm{kDa}$. Soluble materials were recovered by diluting the retentate with distilled water and ethanol $(1: 5 ; v / v)$. U. fasciata polysaccharide extraction was based on the work of Robic et al. [36] and Hardouin et al. [105]. Depigmented samples (10 g) were also extracted sequentially: (1) samples were extracted distilled water $(200 \mathrm{~mL})$ by maceration at $90^{\circ} \mathrm{C}$ for $2 \mathrm{~h}$ and were filtered on Buchner cloth to obtain the aqueous fraction; (2) the crude extract of ulvans was obtained by ethanol precipitation $(1: 5, v / v)$ of the aqueous fraction for $24 \mathrm{~h}$ at $4{ }^{\circ} \mathrm{C}$; and (3) the precipitate obtained (raw ulvan) was filtered, dried, and stored at $-20^{\circ} \mathrm{C}$.

\subsubsection{Monosaccharide Analysis of Polysaccharides}

The simple sugar composition of the samples was determined by high-performance anion-exchange chromatography (HPAEC, Sunnyvale, CA, USA) with pulsed amperometric detection (PAD) (Thermo Dionex, city, France), based on the procedure of Pliego-Cortés et al. [106] with brief modifications. HWE from C. racemosa and crude ulvan from $U$. fasciata (4 $\mathrm{mg} \mathrm{dw}$ each) were subjected to acid hydrolysis for $48 \mathrm{~h}$ at $100{ }^{\circ} \mathrm{C}$ using $110 \mu \mathrm{L}$ of $1 \mathrm{M} \mathrm{HCl}$ and $1 \mathrm{~mL}$ Milli-Q water in a flame-sealed glass ampule. The mixture was neutralized with $110 \mu \mathrm{L}$ of $1 \mathrm{M} \mathrm{NaOH}$ and $780 \mu \mathrm{L}$ of Milli-Q water containing deoxyribose (internal standard) to a final concentration of $50 \mathrm{ppm}$. All samples were filtered with a $0.22 \mu \mathrm{m}$ filter paper. Details of the elution program can be found in Pliego-Cortés et al. [106]. Monosaccharides were identified and quantified based on their standard curves at different concentrations (1.95-125 ppm), including fucose, rhamnose, arabinose, glucosamine, galactose, glucose, mannose, xylose, fructose, ribose, glucoheptose, and glucuronic acid. Results were expressed as micrograms of monosaccharides per milligram of dry weight $\left(\mu \mathrm{g} \mathrm{mg}{ }^{-1} \mathrm{dw}\right)$.

\subsubsection{Fourier-Transform Infrared (FTIR) Spectroscopy}

Spectra of HWE from C. racemosa and crude ulvan from $U$. fasciata were determined using a Nicolet iS 5 FTIR spectrometer (Thermo Scientific, Madison, WI, USA) with a diamond crystal plate. The spectra were recorded in reflexing mode from 4000 to $500 \mathrm{~cm}^{-1}$ as the percentage transmittance with 16 scans of the samples. A background scan with the diamond plate in place was run before each analysis. The detected peaks after Fourier transformation were then compared with algal polysaccharide standards. 


\subsection{Amino Acid Composition}

The amino acid composition of the two species was determined separately by GC-FID after liquid phase hydrolysis of the samples with $6 \mathrm{M} \mathrm{HCl}$ at $110{ }^{\circ} \mathrm{C}$ for $24 \mathrm{~h}$. The amino acid samples were prepared according to the procedure recommended by the EZfaast (Phenomenex, Torrance, CA, USA) method, consisting of a solid-phase extraction step followed by derivatization and a liquid/liquid extraction. Derivatized amino acids were analyzed by gas chromatography coupled to a flame ionization detector (GC-FID, TRACE 1300, Thermo-Fischer Scientific, Milan, Italy), using a Zebron ZB-AAA-GC column (10 $\mathrm{m} \times 0.25 \mathrm{~mm}$, Agilent, CA, USA). Two-microliter samples were introduced into the injector $\left(250^{\circ} \mathrm{C}\right)$ with a split ratio of $1: 10$ and separated using the following program: $110^{\circ} \mathrm{C}$ to $320^{\circ} \mathrm{C}$ (an increase of $32{ }^{\circ} \mathrm{C} / \mathrm{min}$ ), held for $2 \mathrm{~min}$. Nitrogen was used as the carrier gas at a constant flow of $1.7 \mathrm{~mL} / \mathrm{min}$, and the detector was set at $320^{\circ} \mathrm{C}$. The signals were recorded using Chromeleon 7.2 software (Dionex, Thermo-Fischer Scientific, Sunnyvale, CA, USA). Amino acids were identified by their time of retention and quantified by their response factor relative to Norvaline, the internal standard added at a concentration of $200 \mu \mathrm{mol} / \mathrm{L}$.

\subsection{Mineral Analysis by Flame Atomic Absorption Spectrophotometry}

Major mineral elements $(\mathrm{Ca}, \mathrm{Mg}, \mathrm{Na}$, and $\mathrm{K}$ ) and trace elements ( $\mathrm{Fe}, \mathrm{Zn}, \mathrm{Cu}$, and $\mathrm{Mn}$ ) were determined using a PerkinElmer Analyst 200 atomic absorption spectrophotometer (AAS) with a single hollow cathode lamp for each element and an air-acetylene burner. The $200 \mathrm{mg}$ raw samples of dried seaweed were placed into digestion vessels with $1.3 \mathrm{~mL}$ of $1 \mathrm{M} \mathrm{HCl}$, and $19.7 \mathrm{~mL}$ of ultrapure water was added to make the final sample concentration of $10 \mathrm{mg} / \mathrm{ML}$. This was later incubated for $48 \mathrm{~h}$ at $118^{\circ} \mathrm{C}$. Samples were filtered $(0.22 \mu \mathrm{m}$, Minisart High Flow; Sartorius Stedim Biotech, Göttingen, Germany) before analysis. Filtered samples were diluted with distilled water to obtain a $1 \mathrm{mg} / \mathrm{mL}$ concentration. Quantification was performed using standard ranges depending on the element.

\subsection{Pigment Analysis}

Pigment analysis was based on the method used by Silkina et al. [39] with some modifications. Pigment extract from raw material $(20 \mathrm{mg})$ was diluted with methanol $\left(2 \mathrm{~mL}\right.$, at $\left.4{ }^{\circ} \mathrm{C}\right)$ and sonicated (pulse 2, amplitude 100) for $2 \mathrm{~min}$ in test tubes. Samples were kept in the darkroom $\left(4{ }^{\circ} \mathrm{C}, 24 \mathrm{~h}\right)$, centrifuged $(36,000 \times g, 4 \mathrm{~min})$, and then filtered $(0.22 \mu \mathrm{m})$ before analysis. The analysis was performed by high-performance liquid chromatography (HPLC) on a Nucleodur C18 column (EC 250/4.6 100-5 C18ec Macherey-Nagel). A two-solvent elution (eluent A 100\% 0-27 min, eluent B 100\% 27-42 min) was used at a flow rate of $1.4 \mathrm{~mL} / \mathrm{min}$ to separate the pigments (eluent $\mathrm{A}$, methanol/acetonitrile/ammonium acetate $2.3 \mathrm{M}$ in water $(51 / 36 / 13, v / v / v)$; eluent $\mathrm{B}$, ethyl acetate/acetonitrile $(7 / 3, v / v))$. Pigments were detected and characterized by diode array measurements of their absorption spectra recorded between 300 and $600 \mathrm{~nm}$. Chromatograms were registered at $440 \mathrm{~nm}$, and standards of chlorophyll $a$ and $b$ and $\beta$-carotene (Sigma-Aldrich) were used for pigment identification and quantification. Pigment concentrations were expressed as $\mathrm{mg} / \mathrm{g}$.

\subsection{Biological Activities}

\subsubsection{Cytotoxicity and Antiviral Activity of Polysaccharides Evaluated by Cell Viability}

Vero cell lines (line No. ATCC CCL81) were cultivated in Eagle's MEM supplemented with 8\% fetal calf serum (FCS, Eurobio, France); 1\% L-glutamine (200 mM); and 1\% PCS (penicillin (10,000 U), colimycin $(25,000 \mathrm{U})$, and streptomycin $(10 \mathrm{mg}))$. The culture was performed at $37{ }^{\circ} \mathrm{C}$ under a $5 \%$ $\mathrm{CO}_{2}$ atmosphere, and the medium was renewed daily. Herpes simplex virus type 1 (HSV-1; family Herpesviridae) was provided by Pr. Agut (Laboratoire de Dynamique, Epidémiologie et Traitement des Infections Virales de la Pitié Salpêtrière Paris, France). Dilutions of samples $(1 \mu \mathrm{g} / \mathrm{mL}$ to $200 \mu \mathrm{g} / \mathrm{mL})$ were prepared in Eagle's MEM supplemented with 8\% FCS and distributed into a 96-well plate. One hundred microliters of cellular suspension $\left(3.5 \times 10^{5}\right.$ Vero mammalian cells $\left./ \mathrm{mL}\right)$ in supplemented 
Eagle's MEM was added to each well. Cells were infected by the HSV-1 at a multiplicity of infection of $0.001 \mathrm{ID}_{50} /$ cells. The 96-well plate was incubated for three days at $37^{\circ} \mathrm{C}$ with $5 \% \mathrm{CO}_{2}$. Cytotoxicity was tested using cell viability by the neutral red dye method. Optical density (OD) was measured at $540 \mathrm{~nm}$. The $50 \%$ cytotoxic concentration $\left(\mathrm{CC}_{50}\right)$ was defined as the concentration of seaweed extract that reduced the OD of treated cells to $50 \%$ of that of untreated cells. The antiherpetic compound acyclovir was used as a reference inhibitor. The $50 \%$ effective antiviral concentration $\left(\mathrm{EC}_{50}\right)$ was expressed as the concentration that achieved 50\% protection of virus-infected cells [107].

\subsubsection{Antioxidant Activity}

The radical scavenging activity of antioxidant 2,2-diphenyl-1-picrylhydrazyl (DPPH) was determined according to Terme et al. [55]. Solutions of butylated hydroxyanisole (BHA) and butylated hydroxytoluene (BHT) at different concentrations ranging from 1 to $20 \mu \mathrm{g} / \mathrm{mL}$ in methanol (final concentration) were tested as a positive control. Sample solutions of $C$. racemosa and $U$. fasciata HWE and crude ulvan were prepared in different concentrations by diluting the stock solution in water $\left(0-5000 \mu \mathrm{g} / \mathrm{mL}\right.$ ). $\mathrm{IC}_{50}$ (corresponding to the concentration sufficient to obtain $50 \%$ of a maximum scavenging capacity) of samples was determined based on the regression obtained from the dose-response curve.

\section{Conclusions}

The species studied presented different nutritional values based on their nutritional characteristics, while presenting different biological activities. Wild Caulerpa racemosa collected in the Philippines offers real nutritional value based on the results of our studies. The biochemical components found in Ulva fasciata that have the potential for nutraceutical application were palmitic acid and PUFAs (C20:4w6 and C20:5w3). Results obtained from this study suggested that Ulva fasciata could still be utilized as a functional ingredient in the food and health industries because of its considerable amount of $\mathrm{C} 22: 1 \omega 9$ (erucic) and C24:1 $\omega 9$ (nervonic) acids, which are reported to prevent demyelinating disease. In the specific example of antioxidants, our results suggest that fresh seaweed should be preferred for human consumption.

Author Contributions: Design and development: R.P.M., G.B., and N.B. Material preparation and samples collection: R.P.M., and A.Q.H. Experimental work: R.P.M., N.T., H.P.-C., M.L., and C.M. Data analysis: R.P.M., N.T., M.L. and C.M. The first draft of the manuscript was written by R.P.M., and all authors commented on the previous versions of the manuscript. All authors have read and agreed to the published version of the manuscript.

Funding: This research received no external funding.

Acknowledgments: The authors wish to Philippe Douzenel for always being willing to help in every way possible, especially in guiding the use of the gas chromatography apparatus. The first author also wishes to thank the French Embassy in the Philippines for funding his Ph.D. study.

Conflicts of Interest: The authors declare no conflict of interest.

\section{References}

1. Chadwick, R.; Henson, S.; Moseley, B.; Koenen, G.; Liakopoulos, M.; Midden, C.; Palou, A.; Rechkemmer, G.; Schröder, D.; Wright, A. Functional Foods, 1st ed.; Springer: Berlin, Germany; New York, NY, USA, 2003; pp. 1-230. Available online: http://public.eblib.com/choice/publicfullrecord.aspx?p=3099774 (accessed on 23 November 2018).

2. Hamed, I.; Özogul, F.; Ozogul, Y.; Regenstein, J.M. Marine Bioactive Compounds and Their Health Benefits: A Review. Compr. Rev. Food Sci. Food Saf. 2015, 14, 446-465. [CrossRef]

3. Levine, I. Algae: A Way of Life and Health. In Seaweed in Health and Disease Prevention; Fleurence, J., Levine, I., Eds.; Elsevier: Amsterdam, The Netherlands; Academic Press: Cambridge, MA, USA, 2016; pp. 22-27.

4. Henchion, M.; Hayes, M.; Mullen, A.M.; Fenelon, M.A.; Tiwari, B.K. Future Protein Supply and Demand: Strategies and Factors Influencing a Sustainable Equilibrium. Foods 2017, 6, 53. [CrossRef] 
5. De Gaillande, C.; Zubia, M.; Payri, C.; Remoissenet, G. Caulerpa consumption, nutritional value and farming in the Indo-Pacific region. Environ. Biol. Fishes 2016, 29, 2249-2266. [CrossRef]

6. Roohinejad, S.; Koubaa, M.; Barba, F.J.; Saljoughian, S.; Amid, M.; Greiner, R. Application of seaweeds to develop new food products with enhanced shelf-life, quality and health-related beneficial properties. Food Res. Int. 2017, 99, 1066-1083. [CrossRef] [PubMed]

7. Rupérez, P. Mineral content of edible marine seaweeds. Food Chem. 2002, 79, 23-26. [CrossRef]

8. Mæhre, H.K.; Malde, M.K.; Eilertsen, K.-E.; O Elvevoll, E.; Mæhre, H.K. Characterization of protein, lipid and mineral contents in common Norwegian seaweeds and evaluation of their potential as food and feed. J. Sci. Food Agric. 2014, 94, 3281-3290. [CrossRef]

9. MacArtain, P.; Gill, C.I.; Brooks, M.; Campbell, R.; Rowland, I.R. Nutritional Value of Edible Seaweeds. Nutr. Rev. 2007, 65, 535-543. [CrossRef]

10. Ang, P.O., Jr.; Leung, S.M.; Choi, M.M. A verification of reports of marine algal species from the Philippines. Philipp. J. Sci. 2013, 142, 5-49.

11. SIAP. SIAP | Seaweed Industry Association of the Philippines. Available online: http://siap-org.com/ (accessed on 11 February 2019).

12. Bolton, J.J.; Robertson-Andersson, D.V.; Shuuluka, D.; Kandjengo, L. Growing Ulva (Chlorophyta) in integrated systems as a commercial crop for abalone feed in South Africa: A SWOT analysis. Environ. Biol. Fishes 2008, 21, 575-583. [CrossRef]

13. Nardelli, A.; Chiozzini, V.G.; Braga, E.S.; Chow, F. Integrated multi-trophic farming system between the green seaweed Ulva lactuca, mussel, and fish: A production and bioremediation solution. Environ. Biol. Fishes 2018, 31, 847-856. [CrossRef]

14. Tanduyan, S.N.; Gonzaga, R.B.; Bensig, V.D. Off bottom culture of Caulerpa lentillifera in three different water levels in the marine waters of San Francisco, Cebu, Philippines. Galaxea J. Coral Reef Stud. 2013, 15, 123-132. [CrossRef]

15. Bast, F. An illustrated review on cultivation and life history of agronomically important seaplants. In Seaweed: Mineral Composition, Nutritional and Antioxidant Benefits and Agricultural Uses; Nova Science Publishers: Hauppauge, NY, USA, 2014; pp. 39-70.

16. Novaczek, I. A Guide to the Common Edible and Medical Sea Plants of the Pacific Islands. 2001. Available online: http://www.spc.int/DigitalLibrary/Doc/FAME/Manuals/Novaczek_01_MedicinalSeaPlants.html (accessed on 8 August 2019).

17. Hurtado-Ponce, A.Q.; Luhan, M.R.; Guanzon, N.G., Jr. Seaweeds of Panay; Aquaculture Department, Southeast Asian Fisheries Development Center: Iloilo, Philippines, 1992. Available online: http://repository.seafdec.org. ph/handle/10862/560 (accessed on 23 February 2018).

18. Wells, M.L.; Potin, P.; Craigie, J.S.; Raven, J.A.; Merchant, S.S.; Helliwell, K.E.; Smith, A.G.; Camire, M.E.; Brawley, S.H. Algae as nutritional and functional food sources: Revisiting our understanding. Environ. Biol. Fishes 2016, 29, 949-982. [CrossRef] [PubMed]

19. Leandro, A.; Pereira, L.; Gonçalves, A.M.M. Diverse Applications of Marine Macroalgae. Mar. Drugs 2019, 18, 17. [CrossRef]

20. Naylor, J. Production, trade and utilization of seaweeds and seaweed products. In FAO Fisheries Technical Papers (FAO) Documents Techniques FAO sur les Peches (FAO)_Documentos Tecnicos de la FAO Sobre la Pesca (FAO); David Lublin Memorial Library, Food and Agriculture Organization of the United Nations: Rome, Italy, 1976; pp. 1-73.

21. McHugh, D.J. A Guide to the Seaweed Industry; Food and Agriculture Organization of the United Nations: Rome, Italy, 2003; p. 105.

22. Kim, J.-H.; Kang, E.J.; Gil Park, M.; Lee, B.-G.; Kim, K.Y. Effects of temperature and irradiance on photosynthesis and growth of a green-tide-forming species (Ulva linza) in the Yellow Sea. Environ. Biol. Fishes 2010, 23, 421-432. [CrossRef]

23. Serrano, A.E.; Santizo, R.B.; Tumbokon, B.L.M. Potential Use of the Sea Lettuce Ulva lactuca Replacing Soybean Meal in the Diet of the Black Tiger Shrimp Penaeus Monodon Juvenile—ProQuest. 2015. Available online: https://search.proquest.com/openview/7a8092e3eac7faddcbd7f9e870ce1e12/1?cbl= 2046424\&pq-origsite $=$ gscholar (accessed on 20 November 2019).

24. Hurtado-Ponce, A. The Philippine seaweed industry. SEAFDEC Asian Aquac. 1998, 20, 13. 
25. Trono, G.C. Diversity of the seaweed flora of the Philippines and its utilization. Hydrobiologia 1999, 398, 1-6. [CrossRef]

26. Matos, Â.P.; Feller, R.; Moecke, E.H.S.; De Oliveira, J.V.; Júnior, A.F.; Derner, R.B.; Sant'Anna, E.S. Chemical Characterization of Six Microalgae with Potential Utility for Food Application. J. Am. Oil Chem. Soc. 2016, 93, 963-972. [CrossRef]

27. Turan, H. Fatty acid profile and proximate composition of the thornback ray (Raja clavata, L. 1758) from the Sinop coast in the Black Sea. J. Fish. 2007, 1, 97-103. [CrossRef]

28. Rochas, C.; Lahaye, M.; Yaphe, W. Sulfate Content of Carrageenan and Agar Determined by Infrared Spectroscopy. Bot. Mar. 1986, 29, 335-340. [CrossRef]

29. Barbosa, J.D.S.; Costa, M.S.S.P.; De Melo, L.F.M.; De Medeiros, M.J.C.; Pontes, D.D.L.; Scortecci, K.C.; Rocha, H.A.O. In Vitro Immunostimulating Activity of Sulfated Polysaccharides from Caulerpa cupressoides Var. Flabellata. Mar. Drugs 2019, 17, 105. [CrossRef]

30. Sarada, B.; Prasad, M.K.; Kumar, K.K.; Murthy, C.R. Cadmium removal by macro algae Caulerpa fastigiata: Characterization, kinetic, isotherm and thermodynamic studies. J. Environ. Chem. Eng. 2014, 2, 1533-1542. [CrossRef]

31. Gómez-Ordóñez, E.; Rupérez, P. FTIR-ATR spectroscopy as a tool for polysaccharide identification in edible brown and red seaweeds. Food Hydrocoll. 2011, 25, 1514-1520. [CrossRef]

32. Ghosh, P.; Adhikari, U.; Ghosal, P.K.; Pujol, C.A.; Carlucci, M.J.; Damonte, E.B.; Ray, B. In vitro anti-herpetic activity of sulfated polysaccharide fractions from Caulerpa racemosa. Phytochemistry 2004, 65, 3151-3157. [CrossRef] [PubMed]

33. Fernando, I.P.S.; Sanjeewa, K.K.A.; Samarakoon, K.W.; Lee, W.W.; Kim, H.-S.; Kim, E.-A.; Gunasekara, U.K.D.S.S.; Abeytunga, D.T.U.; Nanayakkara, C.; De Silva, E.D.; et al. FTIR characterization and antioxidant activity of water soluble crude polysaccharides of Sri Lankan marine algae. ALGAE 2017, 32, 75-86. [CrossRef]

34. Olasehinde, T.A.; Mabinya, L.V.; Olaniran, A.O.; Okoh, A.I. Chemical characterization of sulfated polysaccharides from Gracilaria gracilis and Ulva lactuca and their radical scavenging, metal chelating, and cholinesterase inhibitory activities. Int. J. Food Prop. 2019, 22, 100-110. [CrossRef]

35. Hernández-Garibay, E.; Zertuche-González, J.A.; Pacheco-Ruíz, I. Isolation and chemical characterization of algal polysaccharides from the green seaweed Ulva clathrata (Roth) C. Agardh. Environ. Biol. Fishes 2010, 23, 537-542. [CrossRef]

36. Robic, A.; Bertrand, D.; Sassi, J.-F.; Lerat, Y.; Lahaye, M. Determination of the chemical composition of ulvan, a cell wall polysaccharide from Ulva spp. (Ulvales, Chlorophyta) by FT-IR and chemometrics. Environ. Biol. Fishes 2008, 21, 451-456. [CrossRef]

37. Hardouin, K. Production of Water Soluble Extracts from Ulva sp. Using Enzymatic Hydrolysis Processes: Characterization, Upgrading and Potential Development. Ph.D. Thesis, University of South Brittany, Lorient, France, 2015.

38. Kazir, M.; AbuHassira, Y.; Robin, A.; Nahor, O.; Luo, J.; Israel, A.; Golberg, A.; Livney, Y.D. Extraction of proteins from two marine macroalgae, Ulva sp. and Gracilaria sp., for food application, and evaluating digestibility, amino acid composition and antioxidant properties of the protein concentrates. Food Hydrocoll. 2019, 87, 194-203. [CrossRef]

39. Silkina, A.; Bazes, A.; Vouvé, F.; Le Tilly, V.; Douzenel, P.; Mouget, J.-L.; Bourgougnon, N. Antifouling activity of macroalgal extracts on Fragilaria pinnata (Bacillariophyceae): A comparison with Diuron. Aquat. Toxicol. 2009, 94, 245-254. [CrossRef]

40. Alam Bhuiyan, K.; Qureshi, S. Proximate Chemical Composition of Sea Grapes Caulerpa racemosa (J. Agardh, 1873) Collected from a Sub-Tropical Coast. Virol. Mycol. 2016, 5, 1000158. [CrossRef]

41. Osuna-Ruiz, I.; Nieves-Soto, M.; Manzano-Sarabia, M.M.; Hernández-Garibay, E.; Lizardi-Mendoza, J.; Burgos-Hernández, A.; Hurtado-Oliva, M.Á. Gross chemical composition, fatty acids, sterols, and pigments in tropical seaweed species off Sinaloa, Mexico. Cienc. Mar. 2019, 45, 101-120. [CrossRef]

42. Ji, H.; Shao, H.; Zhang, C.; Hong, P.; Xiong, H. Separation of the polysaccharides inCaulerpa racemosaand their chemical composition and antitumor activity. J. Appl. Polym. Sci. 2008, 110, 1435-1440. [CrossRef]

43. Hao, H.; Fu, M.; Yan, R.; He, B.; Li, M.; Liu, Q.; Cai, Y.; Zhang, X.; Huang, R. Chemical composition and immunostimulatory properties of green alga Caulerpa racemosa var peltata. Food Agric. Immunol. 2019, 30, 937-954. [CrossRef] 
44. Fleurence, J. Seaweed proteins: Biochemical, nutritional aspects and potential uses. Trends Food Sci. Technol. 1999, 10, 25-28. [CrossRef]

45. Yaïch, H.; Garna, H.; Besbes, S.; Paquot, M.; Blecker, C.; Attia, H. Effect of extraction conditions on the yield and purity of ulvan extracted from Ulva lactuca. Food Hydrocoll. 2013, 31, 375-382. [CrossRef]

46. Rao, Y.P.; Rani, S.D.; Krishna Veni, N.D.; Sirisha, R.I. Seasonal changes of biochemical composition of green algae Ulva fasciata Delile, 1813 and Caulerpa racemosa Agardh, 1873 from coastal waters of Visakhapatnam, east coast of India. Asian J. Plant Sci. Res. 2015, 5, 57-62.

47. Véliz, J.O.; Romero, N.; Robert, P.; Araya, J.; Lopez-Hernandez, J.; Bozzo, C.; Navarrete, E.; Osorio, A.; Ríos, A. Dietary fiber, amino acid, fatty acid and tocopherol contents of the edible seaweeds Ulva lactuca and Durvillaea antarctica. Food Chem. 2006, 99, 98-104.

48. Nunes, N.; Ferraz, S.; Valente, S.; Barreto, M.D.C.; De Carvalho, M.A.A.P. Biochemical composition, nutritional value, and antioxidant properties of seven seaweed species from the Madeira Archipelago. Environ. Biol. Fishes 2017, 29, 2427-2437. [CrossRef]

49. Anh, N.T.N.; Hien, T.T.T.; Hai, T.N. Potential uses of gut weed Enteromorpha spp. as a feed for herbivorous fish. Commun. Agric. Appl. Biol. Sci. 2013, 78, 312-315.

50. Costa, C.A.E.; Alves, A.; Pinto, P.; Sousa, R.; Da Silva, E.B.; Reis, R.L.; Rodrigues, A.E. Characterization of ulvan extracts to assess the effect of different steps in the extraction procedure. Carbohydr. Polym. 2012, 88, 537-546. [CrossRef]

51. Bleakley, S.; Hayes, M. Algal Proteins: Extraction, Application, and Challenges Concerning Production. Foods 2017, 6, 33. [CrossRef] [PubMed]

52. Tahergorabi, R.; Hosseini, S.V. Proteins, Peptides, and Amino Acids. In Nutraceutical and Functional Food Components: Effects of Innovative Processing Techniques; Elsevier: Amsterdam, The Netherlands, 2017; pp. 15-38.

53. Uribe, E.; Vega-Gálvez, A.; García, V.; Pasten, A.; López, J.; Goñi, G. Effect of different drying methods on phytochemical content and amino acid and fatty acid profiles of the green seaweed, Ulva spp. Environ. Biol. Fishes 2018, 31, 1967-1979. [CrossRef]

54. Holdt, S.; Kraan, S. Bioactive compounds in seaweed: Functional food applications and legislation. Environ. Biol. Fishes 2011, 23, 543-597. [CrossRef]

55. Terme, N.; Boulho, R.; Kucma, J.-P.; Bourgougnon, N.; Gilles, B.A.A.B. Radical scavenging activity of lipids from seaweeds isolated by solid-liquid extraction and supercritical fluids. OCL 2018, 25, D505. [CrossRef]

56. McCauley, J.; Winberg, P.; Meyer, B.J.; Skropeta, D. Effects of nutrients and processing on the nutritionally important metabolites of Ulva sp. (Chlorophyta). Algal Res. 2018, 35, 586-594. [CrossRef]

57. Vo, T.-S.; Ngo, D.-H.; Kim, S.-K. Marine algae as a potential pharmaceutical source for anti-allergic therapeutics. Process. Biochem. 2012, 47, 386-394. [CrossRef]

58. FAO/WHO. Fats and Fatty Acids in Human Nutrition; Karger Book: Geneva, Switzerland, 2008. Available online: https://www.karger.com/Book/Home/251867 (accessed on 9 June 2020).

59. Fernandes, C.E.; Vasconcelos, M.A.D.S.; Ribeiro, M.D.A.; Sarubbo, L.A.; Andrade, S.A.C.; Filho, A.B.D.M. Nutritional and lipid profiles in marine fish species from Brazil. Food Chem. 2014, 160, 67-71. [CrossRef]

60. Kumar, M.; Kumari, P.; Trivedi, N.; Shukla, M.K.; Gupta, V.; Reddy, C.R.K.; Jha, B. Minerals, PUFAs and antioxidant properties of some tropical seaweeds from Saurashtra coast of India. Environ. Biol. Fishes 2010, 23, 797-810. [CrossRef]

61. Chan, P.T.; Matanjun, P. Chemical composition and physicochemical properties of tropical red seaweed, Gracilaria changii. Food Chem. 2017, 221, 302-310. [CrossRef]

62. Ulbricht, T.; Southgate, D. Coronary heart disease: Seven dietary factors. Lancet 1991, 338, 985-992. [CrossRef]

63. Sargent, J.; Coupland, K.; Wilson, R. Nervonic acid and demyelinating disease. Med. Hypotheses 1994, 42, 237-242. [CrossRef]

64. Paul, N.A.; Neveux, N.; Magnusson, M.; de Nys, R. Comparative production and nutritional value of "sea grapes"-the tropical green seaweeds Caulerpa lentillifera and C. racemosa. J. Appl. Phycol. 2013. Available online: http://link.springer.com/10.1007/s10811-013-0227-9 (accessed on 23 November 2018). [CrossRef]

65. Matanjun, P.; Mohamed, S.; Mustapha, N.M.; Muhammad, K. Nutrient content of tropical edible seaweeds, Eucheuma cottonii, Caulerpa lentillifera and Sargassum polycystum. J. Appl. Phycol. 2009, 21, 75-80. [CrossRef]

66. Ratana-arporn, P.; Chirapart, A. Nutritional Evaluation of Tropical Green Seaweeds Caulerpa lentillifera and Ulva reticulata. Agric. Nat. Res. 2006, 40 (Suppl. S6), 10. 
67. Misurcova, L. Chemical Composition of Seaweeds. In Handbook of Marine Macroalgae: Biotechnology and Applied Phycology; 2011; pp. 171-192. Available online: https://www.researchgate.net/publication/277698824_ Chemical_Composition_of_Seaweeds (accessed on 23 June 2020).

68. Garcia, J.S.; Palacios, V.; Roldan, A. Nutritional Potential of Four Seaweed Species Collected in the Barbate Estuary (Gulf of Cadiz, Spain). J. Nutr. Food Sci. 2016, 6. Available online: https://www.omicsonline.org/open-access/nutritional-potential-of-four-seaweed-species-collectedin-the-barbateestuary-gulf-of-cadiz-spain-2155-9600-1000505.php?aid=73604 (accessed on 23 June 2020).

69. Chattopadhyay, K.; Adhikari, U.; Lerouge, P.; Ray, B. Polysaccharides from Caulerpa racemosa: Purification and structural features. Carbohydr. Polym. 2007, 68, 407-415. [CrossRef]

70. Wang, J.; Jin, W.; Hou, Y.; Niu, X.; Zhang, H.; Zhang, Q. Chemical composition and moisture-absorption/retention ability of polysaccharides extracted from five algae. Int. J. Biol. Macromol. 2013, 57, 26-29. [CrossRef]

71. Watanabe, T.; Kiron, V.; Satoh, S. Trace minerals in fish nutrition. Aquaculture. 1997, 151, 185-207. [CrossRef]

72. Skikne, B.S.; Lynch, S.R.; Robinson, R.G.; Spicer, J.A.; Cook, J.D. The Effect of Food Consistency on Iron Absorption. Am. J. Gastroenterol. 1983, 78, 5.

73. Dumilag, R.V. Edible Seaweeds Sold in the Local Public Markets in Tawi-Tawi, Philippines. Philipp. J. Sci. 2019, 148, 803-811.

74. Agngrayngay, Z.; Llaguno, A.; Aquino, S.; Taclan, L.; Galacgac, E.S. Edible Seaweeds of Ilocos Norte: Food Preparations, Other Local Uses and Market Potentials; Sulu-Celebes Sea Sustainable Fisheries Management Project: Quezon City, Philippines, 2005. Available online: https://www.scribd.com/document/324409538/ Agngarayngay-etal2050 (accessed on 7 June 2020).

75. Yuan, Y.; Zhang, J.; Fan, J.; Clark, J.; Shen, P.; Li, Y.; Zhang, C.-S. Microwave assisted extraction of phenolic compounds from four economic brown macroalgae species and evaluation of their antioxidant activities and inhibitory effects on $\alpha$-amylase, $\alpha$-glucosidase, pancreatic lipase and tyrosinase. Food Res. Int. 2018, 113, 288-297. [CrossRef] [PubMed]

76. Pirian, K.; Moein, S.; Sohrabipour, J.; Rabiei, R.; Blomster, J. Antidiabetic and antioxidant activities of brown and red macroalgae from the Persian Gulf. Environ. Biol. Fishes 2017, 29, 3151-3159. [CrossRef]

77. Jin, D.-Q.; Lim, C.S.; Sung, J.-Y.; Gil Choi, H.; Ha, I.; Han, J.-S. Ulva conglobata, a marine algae, has neuroprotective and anti-inflammatory effects in murine hippocampal and microglial cells. Neurosci. Lett. 2006, 402, 154-158. [CrossRef]

78. Hsu, C.-Y.; Chao, P.-Y.; Hu, S.-P.; Yang, C.-M. The Antioxidant and Free Radical Scavenging Activities of Chlorophylls and Pheophytins. Food Nutr. Sci. 2013, 4, 1-8. [CrossRef]

79. Okuzumi, J.; Takahashi, T.; Yamane, T.; Kitao, Y.; Inagake, M.; Ohya, K.; Nishino, H.; Tanaka, Y. Inhibitory effects of fucoxanthin, a natural carotenoid, on N-ethyl-N'-nitro-N-nitrosoguanidine-induced mouse duodenal carcinogenesis. Cancer Lett. 1993, 68, 159-168. [CrossRef]

80. Christaki, E.; Bonos, E.; Giannenas, I.; Florou-Paneri, P. Functional properties of carotenoids originating from algae: Functional properties of algal carotenoids. J. Sci. Food Agric. 2013, 93, 5-11. [CrossRef]

81. Percival, E. The polysaccharides of green, red and brown seaweeds: Their basic structure, biosynthesis and function. Br. Phycol. J. 1979, 14, 103-117. [CrossRef]

82. Estevez, J.M.; Fernández, P.V.; Kasulin, L.; Dupree, P.; Ciancia, M. Chemical and in situ characterization of macromolecular components of the cell walls from the green seaweed Codium fragile. Glycobiology 2009, 19, 212-228. [CrossRef]

83. Kidgell, J.T.; Magnusson, M.; de Nys, R.; Glasson, C.R.K. Ulvan: A systematic review of extraction, composition and function. Algal. Res. 2019, 39, 101422. [CrossRef]

84. Lahaye, M.; Robic, A. Structure and functional properties of ulvan, a polysaccharide from green seaweeds. Biomacromolecules 2007, 8, 1765-1774. [CrossRef]

85. Javaid, A.; Bajwa, R.; Shafique, U.; Anwar, J. Removal of heavy metals by adsorption on Pleurotus ostreatus. Biomass Bioenergy 2011, 35, 1675-1682. [CrossRef]

86. Figueira, T.A.; Silva AJR da Enrich-Prast, A.; Yoneshigue-Valentin, Y.; Oliveira, V.P. Structural Characterization of Ulvan Polysaccharide from Cultivated and Collected Ulva fasciata (Chlorophyta). Adv. Biosci. Biotechnol. 2020, 11, 206-216. [CrossRef] 
87. Bouhlal, R.; Haslin, C.; Chermann, J.-C.; Colliec-Jouault, S.; Sinquin, C.; Simon, G.; Cerantola, S.; Riadi, H.; Bourgougnon, N. Antiviral Activities of Sulfated Polysaccharides Isolated from Sphaerococcus coronopifolius (Rhodophytha, Gigartinales) and Boergeseniella thuyoides (Rhodophyta, Ceramiales). Mar. Drugs 2011, 9, 1187-1209. [CrossRef] [PubMed]

88. Wang, L.; Wang, X.; Wu, H.; Liu, R. Overview on Biological Activities and Molecular Characteristics of Sulfated Polysaccharides from Marine Green Algae in Recent Years. Mar. Drugs 2014, 12, 4984-5020. [CrossRef]

89. Mahomoodally, M.F.; Lobine, D.; Rengasamy, K.R.R.; Gowrishankar, S.; Tewari, D.; Zengin, G.; Kim, D.H.; Sivanesan, I. Marine Algae: A Potential Resource of Anti-HSV Molecules. Processes 2019, 7, 887. [CrossRef]

90. Declarador, R.S.; Serrano, A.E., Jr.; Corre, V.L., Jr. Ulvan extract acts as immunostimulant against white spot syndrome virus (WSSV) in juvenile black tiger shrimp Penaeus monodon. Aquac. Aquar. Conserv. Legis. 2014, 7, 153-161.

91. Jiao, G.; Yu, G.; Wang, W.; Zhao, X.; Zhang, J.; Ewart, S.H. Properties of polysaccharides in several seaweeds from Atlantic Canada and their potential anti-influenza viral activities. J. Ocean. Univ. China 2012, 11, 205-212. [CrossRef]

92. Lopes, N.; Ray, S.; Espada, S.F.; Bomfim, W.A.; Ray, B.; Faccin-Galhardi, L.C.; Linhares, R.E.C.; Nozawa, C. Green seaweed Enteromorpha compressa (Chlorophyta, Ulvaceae) derived sulphated polysaccharides inhibit herpes simplex virus. Int. J. Biol. Macromol. 2017, 102, 605-612. [CrossRef]

93. Chiu, Y.-H.; Chan, Y.-L.; Li, T.-L.; Wu, C.-J. Inhibition of Japanese Encephalitis Virus Infection by the Sulfated Polysaccharide Extracts from Ulva lactuca. Mar. Biotechnol. 2012, 14, 468-478. [CrossRef]

94. Aguilar-Briseño, J.A.; Cruz-Suárez, L.E.; Sassi, J.-F.; Ricque-Marie, D.; Zapata-Benavides, P.; Mendoza-Gamboa, E.; Rodriguez-Padilla, C.; Trejo-Avila, L.M. Sulphated Polysaccharides from Ulva clathrata and Cladosiphon okamuranus Seaweeds both Inhibit Viral Attachment/Entry and Cell-Cell Fusion, in NDV Infection. Mar. Drugs 2015, 13, 697-712. [CrossRef]

95. Morán-Santibañez, K.; Cruz-Suárez, L.E.; Ricque-Marie, D.; Robledo, D.; Freile-Pelegrín, Y.; Peña-Hernández, M.A.; Rodríguez-Padilla, C.; Trejo-Avila, L.M. Synergistic Effects of Sulfated Polysaccharides from Mexican Seaweeds against Measles Virus. BioMed Res. Int. 2016, e8502123. Available online: https://www.hindawi.com/journals/bmri/2016/8502123/ (accessed on 8 June 2020). [CrossRef]

96. Sansone, C.; Brunet, C.; Noonan, D.M.; Albini, A. Marine Algal Antioxidants as Potential Vectors for Controlling Viral Diseases. Antioxidants 2020, 9, 392. [CrossRef] [PubMed]

97. Tian, H.; Liu, H.; Song, W.; Zhu, L.; Yin, X. Polysaccharide from Caulerpa lentillifera: Extraction optimization with response surface methodology, structure and antioxidant activities. Nat. Prod. Res. 2019, 12, 1-9. [CrossRef] [PubMed]

98. DuBois Michel Gilles, K.A.; Hamilton, J.K.; Rebers, P.A.; Smith, F. Colorimetric Method for Determination of Sugars and Related Substances. Anal. Chem. 1956, 28, 350-356. [CrossRef]

99. Blumenkrantz, N.; Asboe-Hansen, G. New method for quantitative determination of uronic acids. Anal. Biochem. 1973, 54, 484-489. [CrossRef]

100. Smith, P.K.; Krohn, R.I.; Hermanson, G.T.; Mallia, A.K.; Gartner, F.H.; Provenzano, M.D.; Fujimoto, E.K.; Goeke, N.M.; Olson, B.J.; Klenk, D.C. Measurement of protein using bicinchoninic acid. Anal. Biochem. 1985, 150, 76-85. [CrossRef]

101. Hagerman, A.E.; Butler, L.G. Choosing appropriate methods and standards for assaying tannin. J. Chem. Ecol. 1989, 15, 1795-1810. [CrossRef]

102. Jaques, L.B.; Balueux, R.E.; Dietrich, C.P.; Kavanagh, L.W. A microelectrophoresis method for heparin. Can. J. Physiol. Pharmacol. 1968, 46, 351-360. [CrossRef]

103. Kendel, M.; Wielgosz-Collin, G.; Bertrand, S.; Roussakis, C.; Bourgougnon, N.; Bedoux, G. Lipid Composition, Fatty Acids and Sterols in the Seaweeds Ulva armoricana, and Solieria chordalis from Brittany (France): An Analysis from Nutritional, Chemotaxonomic, and Antiproliferative Activity Perspectives. Mar. Drugs 2015, 13, 5606-5628. [CrossRef]

104. Kumari, P.; Bijo, A.J.; Mantri, V.A.; Reddy, C.R.K.; Jha, B. Fatty acid profiling of tropical marine macroalgae: An analysis from chemotaxonomic and nutritional perspectives. Phytochemistry 2013, 86, 44-56. [CrossRef]

105. Hardouin, K.; Burlot, A.-S.; Umami, A.; Tanniou, A.; Stiger-Pouvreau, V.; Widowati, I.; Bedoux, G.; Bourgougnon, N. Biochemical and antiviral activities of enzymatic hydrolysates from different invasive French seaweeds. Environ. Biol. Fishes 2013, 26, 1029-1042. [CrossRef] 
106. Pliego-Cortés, H.; Bedoux, G.; Boulho, R.; Taupin, L.; Freile-Pelegrín, Y.; Bourgougnon, N.; Robledo, D. Stress tolerance and photoadaptation to solar radiation in Rhodymenia pseudopalmata (Rhodophyta) through mycosporine-like amino acids, phenolic compounds, and pigments in an Integrated Multi-Trophic Aquaculture system. Algal Res. 2019, 41, 101542. [CrossRef]

107. Langlois, M.; Allard, J.; Nugier, F.; Aymard, M. A rapid and automated colorimetric assay for evaluating the sensitivity of herpes simplex strains to antiviral drugs. J. Biol. Stand. 1986, 14, 201-211. [CrossRef]

Sample Availability: Samples of the compounds meta-hydroxydiphenyl (MHDP), bicinchoninic acid (BCA), Bovine Serum Albumin, Folin-Ciocalteu, gallic acid, sulfated dextran, Supelco 37 Component FAME Mix, deoxyribose, fucose, rhamnose, arabinose, glucosamine, galactose, glucose, mannose, xylose, fructose, ribose, glucoheptose, and glucuronic acid, Norvaline, macroelements $(\mathrm{Ca}, \mathrm{Mg}, \mathrm{Na}$, and $\mathrm{K})$, trace elements $(\mathrm{Fe}, \mathrm{Zn}, \mathrm{Cu}$, and $\mathrm{Mn}$ ) chlorophyll $\mathrm{a}$ and $\mathrm{b}$, and $\beta$-carotene, fetal calf serum (FCS), DPPH (2,2-DiPhenyl-1-PicrylHydrazyl), BHA (butylated hydroxyanisole) and Butylated hydroxytoluene (BHT) are available from the authors, while, internal standard for fatty acids, and Mn are not available from the authors.

(C) 2020 by the authors. Licensee MDPI, Basel, Switzerland. This article is an open access article distributed under the terms and conditions of the Creative Commons Attribution (CC BY) license (http://creativecommons.org/licenses/by/4.0/). 